\title{
Citicoline in Ophthalmological Neurodegenerative Disease: A Comprehensive Review
}

\author{
Francesco Oddone ${ }^{1}($ $)$, Luca Rossetti ${ }^{2}$, Mariacristina Parravano ${ }^{1, *}$, Diego Sbardella $^{1}$, Massimo Coletta ${ }^{3}\left({ }^{1}\right.$, \\ Lucia Ziccardi ${ }^{1}{ }^{10}$, Gloria Roberti ${ }^{1}{ }^{1}$, Carmela Carnevale ${ }^{1}$, Dario Romano ${ }^{2}$, Gianluca Manni ${ }^{3}$ \\ and Vincenzo Parisi ${ }^{1}$
}

1 IRCCS-Fondazione Bietti, Via Livenza, 3, 00198 Rome, Italy; oddonef@gmail.com (F.O.); diego.sbardella@fondazionebietti.it (D.S.); luxzic@hotmail.com (L.Z.); gloriaroberti82@gmail.com (G.R.); carmela.carnevale@fondazionebietti.it (C.C.); vmparisi@gmail.com (V.P.)

2 Eye Clinic, ASST Santi Paolo e Carlo, San Paolo Hospital, University of Milan, Via Antonio di Rudinì, 8, 20142 Milan, Italy; luca.rossetti@unimi.it (L.R.); romanodario@gmail.com (D.R.)

3 Department of Clinical Sciences and Translational Medicine, University of Rome Tor Vergata, Viale Oxford 81, 00133 Rome, Italy; coletta@uniroma2.it (M.C.); gianlucamanni53@gmail.com (G.M.)

* Correspondence: mcparravano@gmail.com; Tel.: +39-6-8535-6727

check for updates

Citation: Oddone, F.; Rossetti, L.; Parravano, M.; Sbardella, D.; Coletta, M.; Ziccardi, L.; Roberti, G.;

Carnevale, C.; Romano, D.; Manni, G.; et al. Citicoline in Ophthalmological Neurodegenerative Disease: A Comprehensive Review.

Pharmaceuticals 2021, 14, 281.

https: / /doi.org/10.3390/ph14030281

Academic Editor: Paweł Grieb

Received: 22 February 2021

Accepted: 18 March 2021

Published: 20 March 2021

Publisher's Note: MDPI stays neutral with regard to jurisdictional claims in published maps and institutional affiliations.

\begin{abstract}
Cytidine 5'-diphosphocholine has been widely studied in systemic neurodegenerative diseases, like Alzheimer's disease, Parkinson's disease, and brain ischemia. The rationale for the use of citicoline in ophthalmological neurodegenerative diseases, including glaucoma, anterior ischemic optic neuropathy, and diabetic retinopathy, is founded on its multifactorial mechanism of action and the involvement in several metabolic pathways, including phospholipid homeostasis, mitochondrial dynamics, as well as cholinergic and dopaminergic transmission, all being involved in the complexity of the visual transmission. This narrative review is aimed at reporting both pre-clinical data regarding the involvement of citicoline in such metabolic pathways (including new insights about its role in the intracellular proteostasis through an interaction with the proteasome) and its effects on clinical psychophysical, electrophysiological, and morphological outcomes following its use in ophthalmological neurodegenerative diseases (including the results of the most recent prospective randomized clinical trials).
\end{abstract}

Keywords: retinal ganglion cells; citicoline; apoptosis; proteasome; neuroprotection; neurodegeneration; glaucoma; ischemic optic neuropathy; diabetic retinopathy

\section{Introduction}

Retinal ganglion cells (RGCs) bodies reside in the ganglion cell layer of the inner retina and their axons run above them in the retinal nerve fiber layer to constitute the optic nerve, which brings visual input to the cerebral structure [1].

RGCs may be affected in several pathologies of the visual system, like glaucoma, optic neuritis, and diabetic retinopathy.

Open Angle Glaucoma (OAG) is characterized by a loss of all RGCs compartments: somata, axons, and dendrites. It has been described that several pathogenetic pathways underly RGC death in glaucoma including chronic intermittent ischemia, redox imbalance, excitoxicity, defective axon transport, trophic factor withdrawal, autophagy dysregulation, and accumulation of amyloid beta [2-4].

Moreover, several studies have demonstrated that neuroinflammatory response is strongly involved in glaucoma; the inflammatory pathway can contribute to RGCs loss, due to several stressors, such as, among others, the aberrant purinergic signaling with $\mathrm{P} 2 \mathrm{X} 7$ receptor (P2X7R) activation [5].

Similar mechanisms of RGCs death are involved in optic neuritis, which, together with glaucoma, are the major degenerative causes of optic nerve damage. 
In anterior ischemic optic neuropathy (AION), an irreversible, painless, and acute vascular failure of the optic nerve, cell death cascade is due to many factors, such as an increase of intracellular calcium, excitotoxicity, the generation of free radicals, blood-retinal barrier disruption, inflammation, and apoptosis [6].

In diabetic retinopathy (DR), neurodegeneration is the primary event, and it may precede the development of the characteristic microvascular complications [7]. The targets of this neurodegenerative process are the RGCs and amacrine cells with consequent structural thinning of retinal neuronal and axonal layers at macula [8]. The downregulation and loss of neuroprotective factors, the increase of oxidative stress and lipid peroxidation, the excitotoxicity induced by glutamate, and the dysregulation of pro-inflammatory factors are the main pathogenic mechanisms that are implicated in this process [9].

Given the essential role of neurodegeneration in the pathogenesis of these diseases (OAG, AION, and DR), it is reasonable to hypothesize that therapeutic strategies that are based on neuroprotection may be effective in slowing down RGCs loss.

Among the molecules with neuroprotective effect, citicoline, also known as Cytidine 5'-diphosphocholine, has been widely studied in systemic neurodegenerative diseases, like Alzheimer's disease (AD), Parkinson's disease, and brain ischemia [10]. It is interesting to highlight that, among the common characteristics of AD and Glaucoma, is amyloid beta deposition in the brain and in the retina of AD and glaucoma patients, respectively. Moreover, it has recently been discovered that specific miRNAs are biomarkers and therapeutic targets, in glaucoma and other neurodegenerative diseases, such as AD [11].

Since its very first discovery and usage in preclinical models and in clinics, citicoline has showed a multifactorial mechanism of action linked to phospholipid homeostasis, redox homeostasis, mitochondrial dynamics, cholinergic and dopaminergic neurotransmission [12-14]. As a matter of fact, citicoline displays an identical chemical composition and structure to that of endogenous CDP-choline, a precursor of glycerophospholipid phosphatidylcholine, which is naturally synthesized in living cells, starting from choline and cytidine, through an enzymatic biosynthetic pathway $[15,16]$. Together with phosphatidylethanolamine, phosphatidylcholine is an essential phospholipid for the maintenance of intracellular and extracellular membranes of eukaryotic organisms; these molecules are of particular relevance in surveying neuron homeostasis and functionality, by serving membranes turnover, synaptic plasticity, and neurotransmission [17-19].

Furthermore, citicoline stimulates the biosynthesis of sphingomyelin, a key lipidic metabolite that contributes to the stabilization of plasma membrane of RGC axons. This property further helps the cells to inhibit the release of free fatty acids and it confers additional protection toward redox imbalance, through improved scavenging properties, and to-ward the release of neuroinflammation modulators [15].

Upon oral intake, citicoline is thought to be rapidly absorbed and then hydrolyzed to choline and cytidine in the intestinal wall and liver; therefore, besides providing the metabolic precursors of phospholipids, as cited above, enters synthetic pathways of nucleic acids, proteins, and acetylcholine [20].

Citicoline is envisaged to confer a multifaceted protection towards neurodegeneration by reducing glutamate excitotoxicity and oxidative stress, increasing neurotrophin levels, enhancing the release of neurotransmitters (such as norepinephrine and dopamine), improving axonal transport deficits and supporting axon regeneration, promoting mitochondrial function, and modulating insulin signaling [15,21]. In addition, citicoline prevents ischemia-induced tissue accumulation of free fatty acids and reduces infarct volume and brain edema, thus resulting in an antiapoptotic effect that is related to mitochondrial dependent cell death mechanism [22,23].

Nowadays, citicoline is available as intra-muscular injection oral formulation and eye-drops.

Preclinical data will be discussed in this review as the rationale for the use of citicoline in human pathologies involving RGCs and clinical studies (reporting psychophysical, 
morphological, and electrophysiological evidences) that validated the effect of citicoline in ophthalmological neurodegenerative diseases, like OAG, AION, and DR.

\section{Rationale for the Use of Citicoline in Ophthalmological Neurodegenerative Diseases: Pre-Clinical Data}

Despite the proven therapeutic efficacy, which is widely discussed throughout this text, citicoline pharmacology still lacks solid molecular and biological evidences that support its mechanism(s) of action in vitro and in vivo [16,24].

As far as phospholipids, choline and dopamine, which can be synthesized starting from citicoline metabolites, are macromolecules of key relevance to neuron life, and this biosynthetic-restricted hypothesis on drug activity does not convincingly account for the broad neuroprotective activity that the drug is recognized to display in vitro and in vivo $[16,25]$. Several cellular and mammalian experimental models of brain and retina pathologies, spanning from neurodegeneration, excitotoxicity, metabolic insult, and vascular damage, further discussed below, have raised several concerns regarding the pharmacology of this drug and have long suggested the existence of alternative mechanisms of action of the intact molecule or of the metabolites that it is made of (Table 1).

First, citicoline pharmacokinetic and pharmacodynamic properties do not clarify whether citicoline actually is the active compound, a prodrug, or, more likely, both [16,22,25]. Citicoline has been long thought to rapidly undergo hydrolysis and, probably, dephosphorylation by plasma phosphatases into choline and cytidine and used to de novo synthesize the endogenous CDP-choline, as introduced in the previous paragraph [16,25].

If that is the case, then it is unclear why: (i) upon citicoline absorption, the choline concentration in blood is much lower and not equimolar to that of cytidine; (ii) citicoline is several-fold less toxic in animals than choline, when administered at the same dose, which implies that the choline moiety released upon drug hydrolysis represents only a minor fraction or else it enters, for unknown reasons, into a catabolic pathway more quickly than pure choline does.

Furthermore, the administration of the drug following the topical application of citicoline $2 \%$ ophthalmic solution has recently allowed for detecting the intact drug, together with its metabolites, at a high concentration in the humor vitreous of human subjects, implying that neuroprotection can also likely be achieved in human subjects also with the intact molecule in vivo [26].

Most notably, although citicoline displays a limited stability over time when dissolved in common laboratory buffers (unpublished observation), the robust biological effect, which has been reported in independent experimental settings in vitro (devoid of the blood passage and drug hydrolysis), indeed supports the existence of specific activities of the intact molecule.

As anticipated before, citicoline has shown very significant efficacy in vitro and in vivo in experimental models of vascular, metabolic excitotoxic, and neurodegenerative conditions.

Citicoline administration to rat primary retinal cell cultures conferred protection from apoptosis, by means of a reduced frequency of caspases activation and accumulation of apoptosis markers, in the presence of glutamate-induced excitotoxicity and high glucose challenge [27].

Remarkably, protection against glutamate toxicity had been previously related to the upregulation of glutamate transporters, such as EAAT2 in lipid rafts, in a stroke experimental model [28].

Regarding excitotoxicity, the intraperitoneally injection of citicoline prevented the pathological thickening of retinal layers in a rat experimental model of kainic acid (KA)induced toxicity [29]. In this experimental setting, drug delivery significantly attenuated the extent of cell death, induced intravitreal administration of the glutamate analogue, and further rescued the choline acetyl-transferase and tyrosine hydroxylase immunohistochemical pattern in all retinal layers. On the other hand, a physiological pattern of these enzymes was actually lost upon KA treatment in animals that were not treated with the drug. 
With respect to high glucose, which is highly toxic for neuronal cells, citicoline infusion was reported to improve the viability of retinal cells and reduce the extent of fibers loss upon exposure to high glucose in tissue cultures of mouse retinal explant and in retinal cells that were isolated from Sprague-Dawley rats [30,31]. In both experimental models, citicoline treatment reduced the frequency of apoptotic figures (TUNEL staining) in RGCs population, a finding that was mirrored by the decrease of caspases activation. Furthermore, citicoline restored significant levels of the neurotrophic factor and regenerating neurites.

Citicoline was further found to revert in rat primary retinal neurons the synaptic loss induced by the glucose challenge [27], likely because of a boosting of the neuroprotective role that is exerted by Muller glia cells through the downregulation of the ERK1-ERK2 pathway [32]. Further, neuropharmacological studies have described the neuroprotective and antiapoptotic activities of CDP-choline and of citicoline in rat models of cerebral ischemia through Mitogen Activated Protein Kinase (MAPK) pathways, in particular ERK1-ERK2; therefore, a more detailed molecular investigation on the citicoline-mediated regulation of this central metabolic pathway seems to be required $[30,33]$.

Additional approaches strengthened the protective role of citicoline, which was administered in liposomal formulation, against high glucose in diabetic mice in vivo [34]. In this setting, citicoline opposed the pathological downregulation of synaptophysin in whole retinas, restoring its anti-inflammatory properties (by means of preventing the upregulation of NF-kB and TNF- $\alpha$ (Tumor Necrosis Factor $\alpha$ )). The drug further decreased the extent of retinal reactive gliosis, and it lowered the frequency of apoptotic figures in all retinal elements, such as photoreceptors, bipolar cells, and RGCs [35]. Moreover, the administration of citicoline in eye drops formulation (2\%) improved the reduction of NFL and choroidal thickness, as from OCT investigations, in a mouse model of long-lasting type I diabetes [36]. Specifically, the citicoline effect almost nullified the inverse correlation between the mean glucose level that was monitored in the blood of the animals and progression in ill animals of the nerve fiber layer thickness, in particular of the retinal nerve fiber layer (RNFL) and inner plexiform layer (IPL).

Another stimulating pathway that was shown to be modulated by citicoline is that of sirtuins, a class III histone deacetylases, which plays a multifaceted role in controlling cell energy metabolism, coupling NAD+ sensing with transcription regulation, and, thus, are profoundly implicated in tuning neuroprotective pathways and neuroinflammation, among the others [25]. Citicoline in rat brains induced sirtuins expression, but also in cultured neurons and in lymphomonocytes, and observations in Sirt- / - rats suggested that a significant neurovascular protection that is conferred by citicoline (either directly or indirectly) is determined through SIRT-1 [37].

Similarly, the administration of citicoline, but not of choline or cytidine, was found to be protective in transient cerebral ischemia through the inhibition of phospholipase A2 (PLA2), which turned into a decreased tissue inflammation and redox imbalance [38], properties that were further confirmed in a rat model of ageing [39]. Interestingly, PLA2 hydrolyses cardiolipin, a major phospholipid of mitochondrial membranes, which assists in organelle structure, fission, metabolism, and energy production through oxidative phosphorylation, providing a rationale for the pro-homeostatic role of citicoline [40].

With respect to this last point, the stabilization of mitochondrial membranes, maintenance of energy metabolism, plasma and axons structural and functional integrity, as well as resistance to apoptosis by citicoline are expected to be further achieved through the promotion of sphingomyelin and cardiolipin biosynthesis [15]. Furthermore, it is worth recalling that the stabilization of the plasma membrane through the increased bioavailability of phospholipid precursors helps in preventing glutamate release and toxicity.

In additional experimental models of retina degeneration following optic nerve crush, citicoline administration was associated with an improved viability and delayed degeneration of RGCs through decreased Bcl-2 levels, a pro-apoptotic protein; similarly, pretreatment with the drug prevented the glutamate excitotoxicity death of cerebellar granule cells in vitro [41,42]. 
A relevant pharmacological and molecular hint to explain citicoline biological activity comes from research on the family of sigma- 1 receptor, a chaperone-protein that is located in the Endoplasmic Reticulum (ER), where it plays multifaceted biological functions, including the regulation of $\mathrm{Ca}^{2+}$ flux and activation of neuroprotective pathways, such as autophagy $[43,44]$.

In this framework, choline, which also acts as an intracellular messenger, is an endogenous agonist of sigma-1, providing a molecular link to the activity of this receptor with cholinergic synaptic activity [43].

In the eye, a pioneer study reported the sigma-1 receptor to be highly expressed in the rabbit iris-ciliary body. Indeed, pharmacological modulation of the receptor(s) with the topical administration of selected ligands was shown to modulate retinal protection and intraocular pressure [44]. Furthermore, sigma-1 receptor was found to confer protection to retinal pigment epithelium cells against oxidative stress, improving cell survival and DNA damage, clearly indicating that the modulation of this protein is also an attractive target in ophthalmology disorders as well as in neuro-degenerative disorders [45].

Hence, these studies depict a scenario where citicoline exerts its multifaceted neuroprotective activity by regulating sophisticated metabolic pathways at both the transcriptional and post-synthetic level, envisaging that the drug binds multiple targets, standing at the crossroad of cell metabolism.

Furthermore, the known chemical composition makes it a very versatile molecule and, from a purely biochemical point of view, besides fueling the phospholipid bio-synthetic pathways that are mentioned above, the nucleotide and choline moieties (either alone or phosphorylated and joined together to form the intact citicoline) are particularly suited to dock into the functional or catalytic sites of biological macromolecules through noncovalent interactions. In the case of proteins, it is conceivable that citicoline may modulate their biological and/or enzymological properties, as it is supposed to do with PLA2 for instance.

In this framework, the neuroprotection that is conferred by citicoline may come from those pathways that best cope with the toxic insults post mitotic cells are particularly vulnerable to, such as redox unbalance, proteotoxicity, and alteration of the proteostasis network (PN) [46,47]. PN is a term that defines the equilibrium between protein synthesis and degradation that every cell has to keep balanced to maintain viability, morphological, functional properties, and the fitness of the tissue it belongs to. Nevertheless, the cholinemediate activation of sigma-1 receptor and the downstream effect of this pathway fits with the PN improvement well.

Neurons, as well as other post-mitotic cells, are particularly vulnerable to this kind of insult, since they experience a very accelerated metabolic activity and, at the same time, have not the possibility to dilute the wasting by-products through cell mitosis [46,47]. A paradigmatic example of a PN unbalance, in which the accumulation overrides the bulk degradative capacity, is the deposition of amyloidogenic proteins (e.g., $\mathrm{A} \beta$ peptide in $\mathrm{AD}$, $\alpha$-synuclein in PD, among the others) in the intracellular and extracellular compartments during the onset and progression of neurodegenerative diseases [48,49].

Under homeostatic conditions, the early accumulation of proteotoxic species is balanced by the hyperstimulation of catabolic pathways that survey the proteome expressed at any given time by the cell.

These catabolic pathways are largely known as intracellular proteolytic pathways, e.g., the Ubiquitin Proteasome System (UPS) and autophagy, which are more extensively reviewed elsewhere [50-59].

A recent research by our group cast light on a high affinity interaction of citicoline with the proteasome, a multi-subunit enzymatic assembly that carries out the regulated proteolysis of proteins, usually short-lived, tagged with a poly-ubiquitin chain [56]. 
Table 1. Summary of pre-clinical studies evaluating the therapeutic efficacy and the mechanism of action of Citicoline in vitro and in vivo.

\begin{tabular}{|c|c|c|c|c|c|c|}
\hline Authors & Year & Study Design & Experimental Model & Insult & Citicoline Dose & Main Results \\
\hline Martinet M. et al. [13] & 1979 & Case-Control & Rats & $\mathrm{N} / \mathrm{A}^{\mathrm{a}}$ & 50 mg/ $\mathrm{Kg}^{-1}$ (i.p.) & $\begin{array}{l}\text { Dopamine and tyrosine } \\
\text { synthesis in corpus striatum }\end{array}$ \\
\hline Giménez R. et al. [40] & 1998 & Comparative Study & Sprague-Dawley Rats & $\mathrm{N} / \mathrm{A}^{\mathrm{a}}$ & $\begin{array}{c}100-500 \mathrm{mg} / \mathrm{Kg} \\
\text { (food intake) }\end{array}$ & $\begin{array}{c}\text { PFA }^{\mathrm{b}} \text { accumulation with age } \\
\text { in brain striatum }\end{array}$ \\
\hline Alvarez X.A. et al. [57] & 1999 & Case-Control & Sprague-Dawley Rats & $\begin{array}{l}\text { Hippocampal amyloid beta } \\
\text { injection and permanent } \\
\text { unilateral occlusion of } \\
\text { carotid artery }\end{array}$ & $62.5-250 \mathrm{mg} / \mathrm{Kg}^{-1}$ (i.p.) & $\begin{array}{l}\text { Neuroprotection from A beta } \\
\text { induced degeneration } \\
\text { and hypoperfusion }\end{array}$ \\
\hline Krupinsky J. et al. [37] & 2002 & Case-Control & Sprague-Dawley Rats & $\begin{array}{l}\text { Middle Cerebral } \\
\text { Artery Occlusion }\end{array}$ & $500 \mathrm{mg} / \mathrm{Kg}^{-1}$ (i.p.) & Apoptosis rate in retina layers \\
\hline Rejdak R. et al. [12] & 2002 & Case-Control & Albino Rabbits & $\mathrm{N} / \mathrm{A}^{\mathrm{a}}$ & $50 \mathrm{mg} / \mathrm{Kg}$ (i.p.) & Retinal catecholamine levels \\
\hline Oshitari T. et al. [30] & 2002 & $\mathrm{~N} / \mathrm{A}^{\mathrm{a}}$ & $\begin{array}{l}\text { Tissue Culture of Murine } \\
\text { Retinal Explant }\end{array}$ & High Glucose & $0.1-1 \mu \mathrm{M}$ & $\begin{array}{c}\text { Determination of apoptosis } \\
\text { rate in RGCs }{ }^{\mathrm{c}} ; \\
\text { neurite proliferation }\end{array}$ \\
\hline Adibhatla R.M. et al. [39] & 2003 & & & Transient Cerebral Ischemia & & Effect on PLA2 ${ }^{d}$ activity \\
\hline Krupinsky J. et al. [35] & 2005 & Case-Control & Sprague-Dawley Rats & $\begin{array}{l}\text { Middle Cerebral } \\
\text { Artery Occlusion }\end{array}$ & $500 \mathrm{mg} / \mathrm{Kg}^{-1}$ (i.p.) & $\begin{array}{l}\text { Activation of MAP e kinase } \\
(\text { ERK-1/2) in retinal layers }\end{array}$ \\
\hline Park C.H. et al. [29] & 2005 & Case-Control & Sprague-Dawley Rats & Kainic Acid (KA) & $500 \mathrm{mg} / \mathrm{Kg}^{-1}$ (i.p.) & $\begin{array}{c}\text { Thickness of retinal layers; } \\
\mathrm{IHC}^{\mathrm{f}} \text { staining of ChAT } \mathrm{g} \\
\text { and } \mathrm{TH}^{\mathrm{h}}\end{array}$ \\
\hline Schutteauf F. et al. [42] & 2006 & Case-Control & Brown Norway Rats & Optic Nerve Crush & $0.5 \mathrm{mg}-2 \mathrm{~g} / \mathrm{Kg}$ (i.p.) & RGCs $^{c}$ density; Bcl-2 IHC ${ }^{f}$ \\
\hline Hurtado O. et al. [28] & 2008 & Comparative Study & Fischer Rats & $\begin{array}{l}\text { Middle Cerebral } \\
\text { Artery Occlusion }\end{array}$ & $2 \mathrm{~g} / \mathrm{Kg}^{-1}$ (i.p.) & $\begin{array}{l}\text { Association of EAAT2 with } \\
\text { lipid rafts in rat brain; } \\
\text { glutamate uptake }\end{array}$ \\
\hline Schauss A.G. et al. [24] & 2009 & Toxicol. Study & Sprague-Dawley Rats & $\mathrm{N} / \mathrm{A}^{\mathrm{a}}$ & $\begin{array}{c}\text { Up to } 2000 \mathrm{mg} / \mathrm{Kg} \text { (oral } \\
\text { gavage) }\end{array}$ & $\begin{array}{l}\text { Mortality; blood and renal } \\
\text { parameters assessment }\end{array}$ \\
\hline Oshitari T. et al. [31] & 2010 & $\mathrm{~N} / \mathrm{A}^{\mathrm{a}}$ & $\begin{array}{c}\text { Retinal Cultures of } \\
\text { Sprague-Dawley Rats }\end{array}$ & High Glucose & $1 \mu \mathrm{M}$ & $\begin{array}{l}\text { Apoptosis rate in RGCs }{ }^{c} \\
\text { population (TUNEL assay), } \\
\text { caspases activation; } \\
\text { regenerating neurites }\end{array}$ \\
\hline
\end{tabular}


Table 1. Cont.

\begin{tabular}{|c|c|c|c|c|c|c|}
\hline Authors & Year & Study Design & Experimental Model & Insult & Citicoline Dose & Main Results \\
\hline Hurtado O. et al. [38] & 2013 & $\mathrm{~N} / \mathrm{A}^{\mathrm{a}}$ & $\begin{array}{l}\text { Fischer Rats wild-type } \\
\text { and Sirt1 } 1^{/-}\end{array}$ & Permanent Focal Ischemia & $0.2-2 \mathrm{~g} / \mathrm{Kg}^{-1}$ (i.p.) & $\begin{array}{l}\text { Citicoline efficacy in the } \\
\text { absence of SIRT1 }\end{array}$ \\
\hline Matteucci A. et al. [27] & 2014 & $\mathrm{~N} / \mathrm{A}^{\mathrm{a}}$ & Wistar Rat Embryos & $\begin{array}{l}\text { Excitotoxicity and } \\
\text { High Glucose }\end{array}$ & $10-1000 \mu \mathrm{M}$ & $\begin{array}{c}\text { Apoptosis rate; } \\
\text { caspases activation }\end{array}$ \\
\hline Maestroni S. et al. [36] & 2015 & Comparative Study & C57Bl/6 Mice & Type I Diabetes & $\begin{array}{c}2 \% \\
\begin{array}{c}\text { Citicoline-Ophthalmic } \\
\text { Solution }\end{array}\end{array}$ & $\begin{array}{c}\text { Improvement of retinal layers } \\
\text { thickness, in particular of } \\
\text { RNFL }^{i} \text { and IPL }\end{array}$ \\
\hline Carnevale C. et al. [26] & 2019 & Case-Control & Human & $\mathrm{N} / \mathrm{A}^{\mathrm{a}}$ & $\begin{array}{c}2 \% \\
\text { Citicoline-Ophthalmic } \\
\text { Solution }\end{array}$ & $\begin{array}{l}\text { Citicoline concentration in } \\
\text { humor vitreous }\end{array}$ \\
\hline Sbardella D. et al. [56] & 2020 & $\mathrm{~N} / \mathrm{A}^{\mathrm{a}}$ & $\begin{array}{c}\text { Biochemical assay and } \\
\text { Human Neuron-derived } \\
\text { Cell Lines }\end{array}$ & $\mathrm{N} / \mathrm{A}^{\mathrm{a}}$ & $1-100 \mu \mathrm{M}$ & $\begin{array}{l}\text { Allosteric Modulation of } \\
\text { proteasome; increased UPS } \\
\text { activity in cultured cell lines }\end{array}$ \\
\hline
\end{tabular}

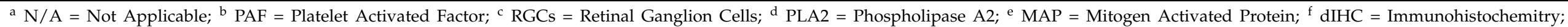

${ }^{\mathrm{g}} \mathrm{ChAT}=$ Chatecolamine Acetyl Transferase; ${ }^{\mathrm{h}} \mathrm{TH}=$ Tyrosine Hydroxylase; ${ }^{\mathrm{i}} \mathrm{RNFL}=$ Retinal Nerve Fiber Layer; ${ }^{\mathrm{l}} \mathrm{IPL}=$ inner plexiform layer; ${ }^{\mathrm{m}}$ UPS: Ubiquitin Proteasome System. 
Citicoline was found to significantly enhance, through a purely allosteric phenomenon, the proteolytic activity of the chymotrypsin-like activity either on synthetic substrates and/or on an amyloidogenic protein, such as $\alpha$-synuclein. In this regard, it is worth pointing out that citicoline was found to milden the accumulation of implanted $A \beta$ peptide in the hippocampus of Sprague-Dawley rats, improving the overall survival of neurons [57]. $\mathrm{A} \beta$ peptide is a proteasome substrate and, notably, is a recognized substrate of enzymes that physiologically interact with this multi-subunit complex, such as Insulin Degrading Enzyme and Neprylisin, which may become an interesting matter of investigation to search out for new biological activities of citicoline [50-52].

Furthermore, citicoline administration to neuron-derived human cells was found to stimulate the clearance of intracellular natural substrates of the UPS (e.g., poly-ubiquitinated proteins) and induce a structural rearrangement of the proteasome particles (increased association of $20 S$ and $19 S$ to form the 265 , see [56]), which maximized the proteolytic burden of the whole UPS over time.

This last point deserves some additional comments. The authors of this review firmly believe that citicoline stimulation of proteasome, if confirmed to occur also in vivo, is likely among the multifaceted ways through which the drug carries out neuroprotection. In this framework, the complex, hierarchical, and chronologically-tuned organization of the UPS provides a solid molecular basis to further explore metabolic pathways that are closely intertwined with it. The proteasome structural modulation documented can be interpreted into two non-mutually exclusive ways, namely: (a) citicoline directly induces a structural phenomenon that stimulates the association of the two proteasome subcomplexes (e.g., $20 S$ and 19S) by increasing the binding affinity and (b) in the presence of citicoline, one or more of those pathways that finely tune proteasome composition gets activated and proteasome modulation is an indirect consequence of upstream events induced by citicoline. Among those reported to affect proteasome activity, it is worth mentioning the Calcium2+dependent Calmodulin Kinase pathways (CamKII) and Protein Kinase A (PKA), which have a profound role in neuroprotection and post-mitotic cells metabolism [59,60].

Therefore, in order to fully characterize the biology of citicoline and to pave the road to further unexplored strategies of intervention based on its usage in clinics, it looks relevant to get clues, from single molecular observation, that allow for working backwards, digging inside the complexity of the intracellular metabolic pathways this small molecule likely joins in vitro and in vivo.

\section{Clinical Data}

Tables 2-4 summarize the psychophysical, morphological, and electrophysiological evidences that were obtained by citicoline treatment in OAG, AION, and DR patients.

\subsection{Open Angle Glaucoma}

Glaucoma is a neurodegenerative disease that is characterized by progressive retinal ganglion cells death. It is one of the most common worldwide causes of irreversible vision loss and its prevalence is increasing, since it is directly related to aging [61]. Quigley and Broman estimated that in 2020 there were almost 80 million people suffering from glaucoma and more than 10 million people bilaterally blind from glaucomatous optic neuropathy [62] The first line therapy in the attempt to stabilize, or at least minimize, the damage to optic nerve head is still based on intraocular pressure (IOP) lowering strategies, but there are cases in which, despite a normal or even low IOP, damage progression can occur [63]. A lot of substances have been proposed to have the capacity to contrast RGCs degeneration in the last decades and citicoline seems to be one of the most promising [64].

Many studies tried to provide evidence that citicoline can be beneficial for glaucoma patients and, from these trials on visual field, visual pathways, and retinal nerve fiber layer in glaucoma patients (Tables 2-4), it emerged that citicoline, administered in addition to the ocular hypotensive therapy, brought about beneficial effects. 


\subsubsection{Psychophysical Evidences}

The first study investigating the clinical benefits of treatment with citicoline on OAG, dates back to 1989, when Pecori Giraldi et al. [65] obtained the first evidence that citicoline can ameliorate the visual field defects in patients with well controlled IOP. In this study, forty-seven eyes from 30 patients suffering from OAG with typical visual field changes were treated with intramuscular administration of citicoline $(1 \mathrm{~g})$ for 10 consecutive days and examined at baseline, after 15 days and three months from the beginning of treatment, with central computerized perimetry (36 eyes), automated perimetry (11 eyes), and applanation tonometry. Despite the presence of many limitations of this study, it was very clear that citicoline could be considered to be a useful complement to the traditional IOP lowering therapies: the authors reported that $75 \%$ of the enrolled eyes had a significant reduction in the scotomatous areas with the central computerized perimetry or in the mean defect with the automated perimetry. In addition, beneficial effects could be maintained for at least three months and the improvement could be boosted if treatment was repeated, without clinically relevant side effects [65]. The same research group conducted another study to evaluate if the positive effects could last for years, with periodically repeated administration cycles. Unlike the first study, in this clinical trial, the enrolled patients were divided into two groups: eleven patients received an intramuscular administration of 1 $\mathrm{g} /$ day of citicoline for 15 days, repeated every six months, while twelve patients in the control group did not receive additional treatment. Patients were clinically tested for 10 years, with an applanation tonometry each month, a complete ophthalmologic examination every three months, and a Video Screen Perimetry every six months. Clinical worsening was defined as the increase of the non-perception area (NPA) on the visual field examination of at least $500 \mathrm{~mm}^{2}$ on at least two consecutive examinations. While, in the untreated group, a progressive NPA increase was found, the citicoline-treated patients had a significant reduction of NPA, with a long-lasting effect that consists in a significant improvement of retinal sensitivity that was confirmed during the next nine years [66]. Although the study groups were small, this was the first relevant evidence that the visual performance among glaucoma patients could be enhanced by a treatment with citicoline [60] and not only by hypotensive therapy [67]. Because people suffering from chronic ophthalmic disease do not usually accept long-term use of intramuscular injections well, further studies tried to find out different routes of administration.

Ottobelli et al. provided more recent evidence of long-term benefits of citicoline in a prospective multicenter open clinical study [68]. In this before-after study, the OAG patients could be eligible if they had a retrospectively documented progression of at least $-1 \mathrm{~dB} /$ year in mean deviation (MD) of Humphrey field analyzer 24-2 SITA Standard visual field (HFA 24-2) for at least three years, despite a good IOP control. During the two-year prospective phase of the study, the enrolled patients were treated with citicoline administered in oral solution (Neukron Ofta ${ }^{\circledR}$, Omikron Italia, Rome, Italy), with the following scheme: one vial per day containing $500 \mathrm{mg}$ of citicoline in oral solution for four months, followed by a two-month wash-out for which a bio-availability of approximately $98 \%$ of the oral solution (similar to that of endovenous administration) was previously documented $[69,70]$. Every patient repeated this cycle four times and a complete ophthalmologic examination and a HFA 24-2 were performed before each study treatment change (baseline plus month 4, 6, 10,12,16,18,22, and 24). At the end of the study, the mean rate of progression (RoP) passed from $-1.1 \mathrm{~dB} /$ year to $-0.15 \mathrm{~dB} /$ year, with a statistically significant difference: treated patients, with a previous fast progression, had only lost 0.3 $\mathrm{dB}$ of $\mathrm{MD}$ in two years. Despite the absence of a control group represents a big limitation of this study, the choice of enrolling fast progressing patients made the results interesting and worthy of further investigations [68].

By using a treatment scheme similar to Ottobelli et al. [68], Lanza et al. [71] evaluated 60 OAG patients with a RoP ranging from -1 to $-1.5 \mathrm{~dB}$ /year in the last two years. In this study, OAG patients that were treated with citicoline administered in oral solution 
(Neukron Ofta ${ }^{\circledR}$, Omikron Italia, Rome, Italy) showed a significant change of RoP that dropped to $-0.45 \mathrm{db} /$ year.

Since 2011 researchers' attention moved in searching a formulation that permits the presence of citicoline in the eye posterior chamber and, therefore, with a potential action near those retinal elements located in the posterior segment that are involved in glaucoma (RGCs).

Thus, a formulation of citicoline by eye drops was developed that contained a solution of $2 \%$ of citicoline in addition to hyaluronic acid and benzalkonium chloride (OMK ${ }^{\circledR}$, Omikron Italia, Rome, Italy) or without benzalkonium chloride in Liposomal Formulation (OMK1-LF ${ }^{\circledR}$, Omikron Italia, Rome, Italy). Two studies, performed in mice [72] and in humans [26], respectively, documented a significant concentration of citicoline and its metabolites in the vitreous chamber after eye drops administration.

By using citicoline that was administered by eye drops (one drop three times/day), Roberti et al. [72] observed that, in OAG patients with an MD up to $12 \mathrm{~dB}$, after two months of treatment, followed by one month of wash-out, the values of HFA 24-2 MD and Pattern Standard Deviation (PSD) did not improve significantly with respect to baseline ones.

It is interesting to report the results of the study conducted by Parisi et al. [73], wherefore, despite a very small population, an MD improvement (defined as a change of at least $1 \mathrm{~dB}$ from baseline) was observed in 17 out of 24 OAG eyes (70\%) after four months of treatment with citicoline administered by eye drops (one drop three times/day).

More recently, a randomized clinical trial (prospective, multicentric, and placebocontrolled study) was performed using citicoline $2 \%$ eye drops $\left(\mathrm{OMK} 1{ }^{\circledR}\right)$ on OAG patients with an MD ranging from -2 to $-15 \mathrm{~dB}$ [74]. In this study, 80 patients were enrolled with a mild RoP in the two years before the baseline visit $(-0.77 \mathrm{~dB} /$ year), despite a good IOP control. Four visits per year for three years were planned: each visit included a complete ophthalmologic examination and an HFA 10-2 and 24-2 tests. After three years of treatment, OAG patients that were treated with citicoline $2 \%$ eye drops showed a slower RoP of both HFA 10-2 and 24-2 MD (-0.14 dB/year and $0.34 \mathrm{~dB} /$ year, respectively), as compared to that observed in OAG patients that were treated with placebo $(-0.74 \mathrm{~dB} /$ year and -0.64 $\mathrm{dB} /$ year, respectively).

\subsubsection{Morphological Evidences}

In addition to psychophysical evidence, the studies conducted by Lanza et al. [71] and Rossetti et al. [74] also evaluated the RNFL thinning on optic nerve head by Optical Coherence Tomography (OCT) examination.

In the first study [71] after 12-months of follow-up, patients that were treated with citicoline administered in oral solution (Neukron Ofta ${ }^{\circledR}$, Omikron Italia, Rome, Italy) showed a significantly slower RNFL thinning, as compared to control group and this difference appeared to be stable in the following 12 months. In nasal and temporal sectors, differences in the RNFL thickness between the two groups were relevant starting at sixmonths follow-up, with higher values in patients that were treated with citicoline. Differences in superior and inferior sectors were significant after 12 months of treatment.

The randomized clinical trial, which was conducted by Rossetti et al. [74], highlighted similar results: patients that were treated with citicoline eye drops $\left(\mathrm{OMK} 1^{\circledR}\right.$, Omikron Italia, Rome, Italy) showed a slower overall RNFL thinning, as compared to placebo group, but, in contrast to the previous study, the difference became statistically significant starting at 30-monhts follow-up. In a more detailed analysis, only inferior sectors showed relevant differences between the two groups. Patients that were treated with citicoline showed a $38 \%$ of reduction of RNFL thinning, with -0.62 micron/year versus -1 micron/year of the placebo group. Thus, the significant association between 10-2 MD changes and RNFL changes suggests that the RoP is influenced by the reduction of the RNFL progressive loss.

At present, studies aiming to compare the reduction of the RNFL progressive loss in OAG patients (homogenous for MD, age and RoP) treated either with eyes drops or systemic solutions/injections containing citicoline are not available. Therefore, actually, it 
is not possible to define whether the effect on RNFL thickness could be differently induced by treatment with citicoline by eye drops or by systemic (oral solution) administration.

\subsubsection{Electrofunctional Evidences}

Different electrophysiological methodologies allow for selectively evaluating RGCs function and the neural conduction along visual pathways.

In particular, the peak-to-peak amplitude between the P50 and N95 components (P50-N95 amplitude) of the Pattern Electroretinogram (PERG) is the electrophysiological index that describes the functional integrity of the innermost retinal layers (RGCs and their fibers) $[75,76]$. By recording Visual Evoked Potential (VEP) and using appropriate visual stimuli (i.e., checkboards subtending either 15 or $60 \mathrm{~min}$. of visual arc), it is possible to obtain bioelectrical responses of the visual cortex that describe the condition of the neural conduction along the small and large axons forming the visual pathways. The main parameter of VEPs responses is the implicit time of the P100 component (P100 implicit time) and the peak-to-peak amplitude between the N75 and P100 components (N75-P100 amplitude) $[77,78]$. In addition, by using simultaneous VEP and PERG recordings, it is possible to derive the electrophysiological index of the post-retinal neural conduction, which is called Retinocortical Time (RCT), calculated by the difference between VEP P100 and PERG P50 implicit times [79].

The first work was published in 1999, in which changes of PERG and VEP responses were observed in relation with the treatment with citicoline [80]. In this study, 40 OAG patients were enrolled with MD between -3 and $-6 \mathrm{~dB}$. They were randomly divided into two groups: 25 OAG patients were treated with citicoline (GC Group) and 15 patients were treated with placebo (GP Group). The GC patients were treated with citicoline that was administered intramuscularly $\left(1000 \mathrm{mg} /\right.$ day, Neuroton ${ }^{\circledR}$, Nuovo Consorzio Sanitario, Rome, Italy) fir 60 days. GP patients were treated with placebo for 60 days. At day 180 (after two months of wash-out), GC patients were sub-grouped: in 10 patients (GC1 group) the washout was prolonged for further 120 days; in 15 patients (GC2 group), a second treatment with intramuscular citicoline was administered for 60 days, followed by 120 days of washout. By contrast, in GP patients, at day 180, another period of washout was proposed for additional 180 days.

GP patients displayed similar values of PERG and VEP parameters and of RCT in all examinations performed. In GC patients, the treatment with citicoline induced a significant improvement of PERG and VEP parameters and of RCT values. After washout, in GC patients, although there was a worsening trend, the values of PERG and VEP parameters and of RCT were still improved. After a second period of washout, GC1 patients showed PERG and VEP and RCT values that were similar to baseline ones and to those of GP patients; by contrast, in GC2 patients, a second period of citicoline treatment induced a further improvement of the values of PERG and VEP parameters and of RCT.

This work was very relevant, because it suggested that citicoline may induce a real effect of neuroenhancement [2] on RGCs and on axons forming the visual pathways; this contrasted with the idea that the primary observed visual filed changes in OAG after treatment with citicoline [66] could be related to an increase of the consciousness level $[74,81]$ with a better performance during the execution of the psychophysical test.

In a part of the patients (12 GC and 12 GP) enrolled in this study [80], the follow up was extended to a total period of 96 months [82]. In GC patients, a second treatment with intramuscular citicoline of two months was performed for 16 periods in eight years. Each treatment segment was followed by four months of wash-out. In the following periods (13-96 months) of citicoline administration, a great improvement of VEP and PERG values as well as RCT index was observed in GC patients, when comparing the data to the pre-treatment condition and to those observed in GP patients.

In addition, during the same period of follow-up, a worsening of the visual field defects was detected in GP patients, whereas, in the GC group, MD stabilization or im- 
provement was found and the MD changes were significantly related to the increase of PERG P50-N95 amplitudes and to the shortening of both VEP P100 implicit times and RCTs.

In 2003, Rejdak et al. [83] suggested the administration of citicoline by oral route (one tablet containing $1000 \mathrm{mg}$ of citicoline/day for 56 days) in OAG, and they observed a shortening of VEPs P100 implicit time in $62 \%$ of treated patients.

In 2008, Parisi et al. [84] published a work involving OAG patients with an MD between -2 and $-14 \mathrm{~dB}$, where the effects on PERG and VEP responses of the intramuscular treatment with citicoline $\left(1000 \mathrm{mg}\right.$ /day intramuscularly, Cebroton ${ }^{\circledR}$, Tubilux Pharma, Pomezia, Rome, Italy) were compared to those that were related to a treatment performed administrating citicoline in oral suspension $\left(1600 \mathrm{mg} /\right.$ day, Cebrolux ${ }^{\circledR}$, Tubilux Pharma, Pomezia, Rome, Italy) for two sequential periods of two months of treatment (each followed by four months of wash-out) during a total period of 12 months of follow-up. The main result of this study was that the changes of the values of all electrophysiological parameters (i.e., PERG P50 or VEP P100 implicit times, PERG P50-N95 amplitudes, and RCT) were not statistically different between the two different types of citicoline administration.

The possible improvement of RGCs function and the neural conduction has been also evaluated when citicoline was available by eye drop administration.

In 2014 [72], 2015 [73], and 2019 [85], studies describing treatment with citicoline administered by eye drops with benzalkonium chloride $\left(\mathrm{OMK} 1^{\circledR}\right.$, Omikron Italia, Rome, Italy) or preservative free formulation with a Liposomal System $\left(\mathrm{OMK1}-\mathrm{LF}^{\circledR}\right.$, Omikron $^{\circledR}$ Italia, Rome, Italy) as carrier for citicoline were published. It was reported that citicoline eye drops induces an improvement of the PERG P50-N95 amplitudes and a shortening of VEPs P100 implicit times in OAG patients with an MD between -2 and $-6 \mathrm{~dB}$, either treated for a period of two [72] or four $[73,85]$ months. It was interesting to observe that, when OAG patients were treated with OMK ${ }^{\circledR}[73]$, the improvement of RGCs function (detected by an increase of PERG P50-N95 amplitude) and neural conduction along the visual pathways (detectable from the shortening of the VEPs P100 implicit time) induced an improvement of HFA 24-2 MD with a RoP of $0.56 \mathrm{~dB}$; by contrast, in OAG patients, which were treated exclusively with hypotensive drops, the RoP was of $-0.24 \mathrm{~dB}$.

\subsection{Anterior Ischemic Optic Neuropathy}

AION is the most common type of acute optic neuropathy in subjects that were aged more than 50 years, due to a deficit of blood supply to the optic nerve from the posterior ciliary arteries [86,87]. It represents an ophthalmological emergency, which is characterized by sudden and severe visual loss, visual field deficit, peripapillary hemorrhages, and optic nerve head swelling. AION can be non-arteritic (NAION) or arteritic (AAION), with a different prognosis, commonly being NAION, a self-limiting process accompanied by a partial resolution of the visual loss, and leading AAION to a more detrimental impairment of vision up to blindness [87]. Controversies on pathogenesis, systemic and local risk factors, clinical features, and especially on the management of NAION are due to various misconceptions [88]. Regarding the pharmacological management, it is generally accepted that systemic steroid therapy during early stages of NAION has a significant beneficial effect for visual outcome.

Emerging neuroprotective treatments have been reported to counteract secondary neurodegeneration of RGCs and their axons [88]. Specifically, pivotal studies have described the efficacy of oral citicoline to enhance RGCs and visual pathway's function (neuroenhancement) [89,90], as well as to induce the preservation of RGCs fibers (neuroprotection) [90]. The rationale of neuroprotection in NAION resides in the fact that not $100 \%$ of the axons forming the optic nerve die during an ischemic process, but only a portion of them is damaged. The surviving axons belonging to not damaged RGCs, which are responsible for the residual visual acuity and visual field sparing, are the targets of any protective strategy for subsequent improvement [88,91].

Here, we provide details on the effect on visual acuity and visual field, visual pathways and RGCs' function, and RNFL structure in chronic NAION patients, after the administration of oral citicoline available since 2005 as an oral dietary supplement (Tables 2-4). 
Table 2. Summary of clinical studies evaluating the effects of Citicoline in human ophthalmological neurodegenerative disease: electrophysiological evidences.

\begin{tabular}{|c|c|c|c|c|c|c|c|}
\hline Authors & Year & Study Population & Administration & Dosage & Schedule of Treatment & Follow-up & Main Results \\
\hline Parisi V. et al. [80] & 1999 & $\begin{array}{l}\mathrm{OAG}^{\text {a }} \text { with } \\
\mathrm{MD}^{\mathrm{g}}-3 /-6 \mathrm{~dB}\end{array}$ & $\mathrm{IM}^{\mathrm{b}}$ & $1000 \mathrm{mg} /$ day & $\begin{array}{l}2 \text { cycles of } 60 \text { days of } \\
\text { treatment each followed by } \\
120 \text { days of wash-out }\end{array}$ & 360 days & $\begin{array}{l}\text { Increase in PERG }{ }^{c} \text { P50-N95 and in VEP }{ }^{d} \text { N75-P100 } \\
\text { as }^{e} \text { Shortening in PERG }{ }^{c} \text { P50 and VEP }{ }^{d} \text { P100 Its }\end{array}$ \\
\hline Redjak R. et al. [83] & 2003 & $\mathrm{OAG}^{\mathrm{a}}$ & Tablet & $1000 \mathrm{mg} /$ day & $\begin{array}{l}1 \text { cycle of } 56 \text { day } \\
\text { of treatment }\end{array}$ & 56 days & Shortening in PERG ${ }^{c}$ P50 and VEP ${ }^{d}$ P100 Its ${ }^{f}$ \\
\hline Parisi V. [82] & 2005 & $\begin{array}{l}\mathrm{OAG}^{\mathrm{a}} \text { with } \\
\mathrm{MD}^{\mathrm{g}}-3 /-6 \mathrm{~dB}\end{array}$ & $\mathrm{IM}^{\mathrm{b}}$ & $1000 \mathrm{mg} /$ day & $\begin{array}{l}14 \text { cycles of } 60 \text { days of } \\
\text { treatment each followed by } \\
120 \text { days of wash-out }\end{array}$ & 8 years & $\begin{array}{l}\text { Increase in PERG }{ }^{c} \text { P50-N95 and in VEP }{ }^{d} \text { N75-P100 } \\
\text { as }^{\mathrm{e}} \text {; Shortening in PERG }{ }^{\mathrm{c}} \text { P50 and VEP }{ }^{\mathrm{d}} \text { P100 Its } \\
\text { Correlation with Visual Field improvement. }\end{array}$ \\
\hline Parisi V. et al. [84] & 2008 & $\begin{array}{l}\mathrm{OAG}^{\mathrm{a}} \text { with } \\
\mathrm{MD}^{\mathrm{g}}-2 /-14 \mathrm{~dB}\end{array}$ & $\mathrm{IM}^{\mathrm{b}}$ Oral & $\begin{array}{l}1000 \mathrm{mg} / \text { day } \\
1600 \mathrm{mg} / \text { day }\end{array}$ & $\begin{array}{l}2 \text { cycles of } 60 \text { days of } \\
\text { treatment each followed by } \\
120 \text { days of wash-out }\end{array}$ & 360 days & $\begin{array}{l}\text { Increase in PERG }{ }^{c} \text { P50-N95 and in VEP }{ }^{d} \text { N75-P100 } \\
\text { as }^{\mathrm{e}} \text { Shortening in PERG }{ }^{\mathrm{c}} \text { P50 and VEP }{ }^{\mathrm{d}} \mathrm{P} 100 \mathrm{Its}^{\mathrm{f}} \\
\text { Non-significant differences between } \mathrm{IM}^{\mathrm{b}} \text { and } \\
\text { Oral treatment. }\end{array}$ \\
\hline Parisi V. et al. [89] & 2008 & NAION $^{h}$ & Oral Suspension & $1600 \mathrm{mg} /$ day & $\begin{array}{l}2 \text { cycles of } 60 \text { days of } \\
\text { treatment each followed by } \\
120 \text { days of wash-out }\end{array}$ & 360 days & $\begin{array}{l}\text { Increase in PERG }{ }^{c} \text { P50-N95 and in VEP }{ }^{d} \text { N75-P100 } \\
\text { as }^{e} \text { Shortening in PERG }{ }^{c} \text { P50 and VEP }{ }^{d} \text { P100 Its }\end{array}$ \\
\hline Roberti G. et al. [72] & 2014 & $\begin{array}{l}\mathrm{OAG}^{\mathrm{a}} \text { with } \\
\mathrm{MD}^{\mathrm{g}}-2 /-14 \mathrm{~dB}\end{array}$ & Eye drops & 3 drops/day & $\begin{array}{l}60 \text { days of treatment } \\
\text { followed by } 30 \text { days of } \\
\text { wash-out }\end{array}$ & 90 days & $\begin{array}{c}\text { Increase in PERG }{ }^{\mathrm{c}} \text { P50-N95 as }{ }^{\mathrm{e}} \\
\text { Shortening in PERG }{ }^{\mathrm{c}} \mathrm{P} 50 \mathrm{Its}^{\mathrm{f}} \\
\text { Association with Visual Field improvement. }\end{array}$ \\
\hline Parisi V. et al. [73] & 2015 & $\begin{array}{l}\mathrm{OAG}^{\mathrm{a}} \text { with } \\
\mathrm{MD}^{\mathrm{g}}>12 \mathrm{~dB}\end{array}$ & Eye drops & 3 drops/day & $\begin{array}{l}120 \text { days of treatment } \\
\text { followed by } 60 \text { days of } \\
\text { wash-out }\end{array}$ & 180 days & $\begin{array}{l}\text { Increase in PERG }{ }^{\mathrm{c}} \mathrm{P} 50-\mathrm{N} 95 \text { and in VEP }{ }^{\mathrm{d}} \text { N75-P100 } \\
\text { as }^{\mathrm{e}} \text { Shortening in PERG }{ }^{\mathrm{c}} \text { P50 and VEP } \mathrm{d} \text { P100 Its } \\
\text { Correlation with Visual Field improvement. }\end{array}$ \\
\hline Parisi V. et al. [90] & 2019 & $\mathrm{NAION}^{\mathrm{h}}$ & Oral Solution & $500 \mathrm{~mL} /$ day & $\begin{array}{l}180 \text { days of treatment } \\
\text { followed by } 90 \text { days of } \\
\text { wash-out }\end{array}$ & 2700 days & $\begin{array}{l}\text { Increase in PERG }{ }^{c} \text { P50-N95 and in VEP }{ }^{d} \text { N75-P100 } \\
\text { as }^{e} \text { Shortening in PERG }{ }^{c} \text { P50 and VEP }{ }^{d} \text { P100 Its } \\
\text { f } \\
\text { Association with Visual Field or RNFL-T }{ }^{1} \\
\text { stabilization or improvement. }\end{array}$ \\
\hline
\end{tabular}

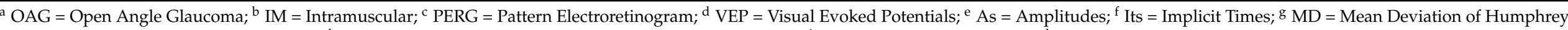
field analyzer 24-2 SITA Standard strategy; ${ }^{\mathrm{h}}$ NAION= Non-arteritic Anterior Ischemic Optic Neuropathy; ${ }^{\mathrm{i}}$ LF $=$ Liposomal Formulation; ${ }^{1}$ RNFL-T= Retinal Nerve Fiber Layer Thickness. 


\subsubsection{Psychophysical Evidences: Visual Acuity}

After citicoline treatment in oral suspension $\left(1600 \mathrm{mg} /\right.$ day Cebrolux ${ }^{\circledR}$, Tubilux Pharma, Pomezia, Rome, Italy), for two cycles of administration of 60 days each, interrupted by a wash-out period of four months, a significant increase in Visual Acuity (VA) in the 14 NAION treated eyes [89] was found. A reduction in VA was observed after the first wash-out period, though ameliorated with respect to the baseline values; over the same period, no significant VA changes were detected in the 12 not treated patients. After this initial steep increase, only a little progression of the VA at the end of the second two month treatment phase (180-240 days) was observed. After the second wash-out period, VA decreased, even though the values were still lower than the basal ones, maintaining the improvement in VA.

The effects of the treatment with citicoline administrated in oral solution (one vial of $500 \mathrm{mg}$ daily, Neukron Ofta ${ }^{\circledR}$, Omikron Italia, Rome, Italy) on 19 NAION patients for six months, followed by three months of wash-out were also studied [90]. Significant individual changes for VA in the citicoline treated NAION patients were observed after six months and at nine months of evaluation.

\subsubsection{Psychophysical Evidences: Visual Field}

In the latter study [90], the HFA 24-2 MD after treatment with citicoline administered in oral solution was also assessed. When comparing six and nine months to the baseline values, an MD improvement in $74 \%$ of treated patients was found. By contrast, an MD worsening was detected in $70 \%$ of 16 not treated NAION patients.

\subsubsection{Morphological Evidences}

A morphological impairment of RNFL, characterized by initial swelling in the acute phase and by sectorial or diffuse thinning in the chronic phase of NAION, has been widely studied by using spectral domain (SD-OCT) [92]. More recently, it was also confirmed that, in chronic NAION, a selective impairment of the inner retina occurs, with outer retina sparing from neurodegeneration, as detected by segmenting the retinal layers that were scanned by SD-OCT [93].

When citicoline in oral solution was administered to chronic NAION patients for six months [90], SD-OCT RNFL thickness (RNFL-T) was used as the morphological index to describe the integrity of RGCs fibers forming the optic nerve. This was investigated to unveil the potential effect of neuroprotection on the optic nerve by exogenous citicoline. At baseline, both treated and not-treated NAION Groups showed a significant reduction in RNFL-T in all sectors as compared to Controls. This was likely due to loss of nerve fibers typical of the chronic NAION, and described to occur right after one or two months from the acute onset of visual loss [94-96].

After six months of treatment with citicoline in oral solution, a large percentage of eyes showed unmodified or improved RNFL overall thickness, with no worsening. By contrast, untreated NAION eyes showed a significant progressive thinning of the overall RNFL. These relevant results were attributed to the potential property of citicoline to limit RGCs and their fibers death [90], as suggested by the effect of citicoline in controlling neuronal apoptosis and inducing the regeneration of new-born RGCs neurites in experimental models [31,97].

\subsubsection{Electrofunctional Evidences}

Because VA and visual field are psychophysical parameters, highly subjective and influenced by the suggested citicoline effect of increased level of consciousness and attention $[81,98]$, it was considered that VA and visual field were not the best parameters that are able to describe the potential beneficial effect of citicoline for enhancing visual function. Therefore, in the clinical practice settings and reported studies [89,90], psychophysical data are always combined with more objective, not invasive electrophysiological data.

PERG P50-N95 amplitude, as well as VEPs P100 implicit time and N75-P100 amplitude, have been widely used in the clinical settings of NAION to assess RGCs dysfunction $[89,99,100]$ and the impairment of neural conduction along the visual pathway [89,101,102], respectively. 
In a previous NAION study [89], the simultaneous PERG and VEP recordings were used to assess the effect of citicoline that was administered in oral suspension $\left(\right.$ Cebrolux ${ }^{\circledR}$, Tubilux Pharma, Pomezia, Rome, Italy) on the whole visual pathways from the RGCs to the visual cortex, knowing that it was significantly impaired as compared to the Controls. At the end of the two periods of treatment with citicoline a significant enhancement (with respect to baseline and not treated NAION) of the RGCs function was found, as suggested by greater PERG P50-N95 amplitude and by the reduction in PERG P50 implicit time in NAION treated patients.

The improvement of RGCs function was accompanied by an enhancement of the function of the visual pathways, as demonstrated by ameliorated VEPs parameters (shortening of VEP P100 implicit times and improved N75-P100 amplitudes) and by better values of VA. After washout, the improvement of PERG values persisted as compared to the baseline condition. Therefore, unlike VA, which first improved and then stabilized, PERG and VEP improvement steadily progressed throughout the treatment period, only in NAION treated patients.

In a more recent study on the administration of citicoline in oral solution (Neukron Ofta ${ }^{\circledR}$, Omikron Italia, Rome, Italy) to NAION patients [90], a significant positive change in individual PERG P50-N95 amplitude, VEP P100 implicit time, and VEP N75-P100 amplitude at six months follow-up was found, as compared to the baseline; the VEP P100 implicit time shortening was not significantly correlated with relative changes in PERG amplitude. In contrast, in not treated NAION patients, no significant VEP changes were observed, while a significant reduction in PERG P50-N95 amplitude was detected by comparing the data to baseline values. In this pivotal study [90], the lack of a significant correlation between electrophysiological (PERG and VEP values) and morphological (RNFL-T values) data was also observed, and this suggests that citicoline administered in oral solution has concomitant, but unrelated, functional and structural effects on RGCs axons.

\subsection{Diabetic Retinopathy}

DR represents one of the most important complications of diabetes and preventable causes of visual impairment among people of working age and industrialized countries [103,104]. A high prevalence of DR of up to $86 \%$ in patients with type 1 diabetes mellitus (DM1) in Europe, south Asia, and the USA has been reported [105,106]. Genetic factors, the duration of the disease, poor glycemic control and variability, hyperlipidemia, and hypertension are considered to be important risk factors for the development and progression of DR [107-111].

Although DR has been always been considered to be a microvascular disease, in the early stages a degeneration of neural retinal elements, such as RGCs, has been demonstrated and it could be implicated in the development of the microvascular damage [112-115].

The retinal neurodegeneration could be induced by several factors, such as the increase of excitoxic metabolites (e.g., glutamate, branched chain amino acids, and homocysteine), the decrease of folic acid and vitamin B12 [116] or the activation of inflammasome by P2X7 receptor [117-119].

Many data support the role of the Citicoline on RGC by increasing its function (neuroenhancement) and preventing the neurodegeneration (neuroprotection) (see, as a review, Faiq et al. [15]). Recently, the effects of citicoline and vitamin B12 administered in eye drops on function, structure, and vascular condition of central retina in type 1 patients with mild signs of DR during a period of 36 months in comparison with placebo have been reported [120].

In this study, twenty patients were enrolled with DM1 and mild signs of non-proliferative diabetic retinopathy (NPDR); they were randomly divided into two groups, namely (a) the DC group, including patients that were treated with citicoline and vitamin B12 eye drops, and (b) the DP group, including those treated with placebo. In the DC group, one eye of each patient was treated with citicoline and vitamin B12 eye drops (three drops/day, OMK2 ${ }^{\circledR}$, Omikron Italia, Rome, Italy), while, in the DP group, it was treated with placebo (three drops/day, eye drops containing hypromellose $0.3 \%$ ) for 36 months. In both of the groups, Humphrey Matrix frequency doubling technology (FDT), SD-OCT and OCT angiography (OCTA), and adaptive optics (AO) were performed at baseline, and 12, 24, and 36 months of the follow-up period. 
Table 3. Summary of clinical studies evaluating the effects of citicoline in human ophthalmological neurodegenerative disease: psychophysical evidences.

\begin{tabular}{|c|c|c|c|c|c|c|c|}
\hline Authors & Year & Study Population & Administration & Dosage & Schedule of Treatment & Follow-up & Main Results \\
\hline Pecori Giraldi J. et al. [65] & 1989 & $\mathrm{OAG}^{\mathrm{a}}$ & $\mathrm{IM}^{\mathrm{b}}$ & 1000 mg/day & 10 days & 90 days & $\begin{array}{l}\text { Visual Field improvement } \\
\text { and stability }\end{array}$ \\
\hline Virno M. et al. [66] & 2000 & $\mathrm{OAG}^{\mathrm{a}}$ & $\mathrm{IM}^{\mathrm{b}}$ & 1000 mg/day & $\begin{array}{l}20 \text { cycles of } 15 \text { days of } \\
\text { treatment each followed } \\
\text { by } 180 \text { days of wash-out }\end{array}$ & 10 years & Visual Field improvement \\
\hline Parisi V. et al. [82] & 2005 & $\begin{array}{c}\mathrm{OAG}^{\mathrm{a}} \text { with } \\
\mathrm{MD}^{\mathrm{g}}-3 /-6 \mathrm{~dB}\end{array}$ & $\mathrm{IM}^{\mathrm{b}}$ & 1000 mg/day & $\begin{array}{l}14 \text { cycles of } 60 \text { days of } \\
\text { treatment each followed } \\
\text { by } 120 \text { days of wash-out }\end{array}$ & 8 years & $\begin{array}{l}\text { Visual Field improvement } \\
\text { correlated with: Increase in PERG } \\
\text { P50-N95 and in VEP d } \\
\text { N75-P100 as }{ }^{\mathrm{e}} \text {; } \\
\text { Shortening in PERG }{ }^{\mathrm{c}} \text { P50 and VEP } \\
\mathrm{d}_{\mathrm{d}} \text { P100 Its }{ }^{\mathrm{f}}\end{array}$ \\
\hline Parisi V. et al. [89] & 2008 & $\mathrm{NAION}^{\mathrm{h}}$ & Oral Suspension & $1600 \mathrm{mg} /$ day & $\begin{array}{l}2 \text { cycles of } 60 \text { days of } \\
\text { treatment each followed } \\
\text { by } 120 \text { days of wash-out }\end{array}$ & 360 days & $\begin{array}{l}\text { Increase in PERG }{ }^{\mathrm{c}} \mathrm{P} 50-\mathrm{N} 95 \text { and in } \\
\text { VEP }^{\mathrm{d}} \text { N75-P100 as } \\
\text { e SERG Shtening in }^{\mathrm{c}} \mathrm{P} 50 \text { and VEP } \\
\text { d P100 Its }\end{array}$ \\
\hline Ottobelli L. et al. [68] & 2013 & Progressive $\mathrm{OAG}^{\mathrm{a}}$ & Oral Solution & $500 \mathrm{mg} /$ day & $\begin{array}{l}4 \text { cycles of } 120 \text { days of } \\
\text { treatment each followed } \\
\text { by } 60 \text { days of washout }\end{array}$ & 2 years & $\begin{array}{l}\text { Reduction of Visual Field rate } \\
\text { of progression }\end{array}$ \\
\hline Roberti G. et al. [72] & 2014 & $\begin{array}{c}\mathrm{OAG}^{\mathrm{a}} \text { with } \\
\mathrm{MD}^{\mathrm{g}}-2 /-14 \mathrm{~dB}\end{array}$ & Eye drops & 3 drops/day & $\begin{array}{l}60 \text { days of treatment } \\
\text { followed by } 30 \text { days of } \\
\text { wash-out }\end{array}$ & 90 days & $\begin{array}{l}\text { Visual Field improvement } \\
\text { associated to: Increase in PERG } \\
\text { P50-N95 as } \\
\text { e } \\
\text { Shortening in PERG }{ }^{\mathrm{c}} \text { P50 Its }\end{array}$ \\
\hline Parisi V. et al. [73] & 2015 & $\begin{array}{l}\mathrm{OAG}^{\mathrm{a}} \text { with } \\
\mathrm{MD}^{\mathrm{g}}>12 \mathrm{~dB}\end{array}$ & Eye drops & 3 drops/day & $\begin{array}{c}120 \text { days of treatment } \\
\text { followed by } 60 \text { days of } \\
\text { wash-out }\end{array}$ & 180 days & 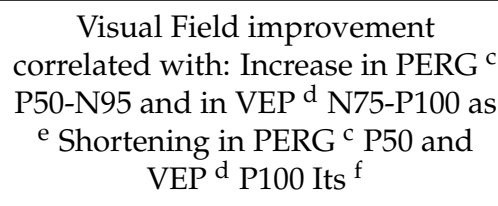 \\
\hline Parisi V. et al. [85] & 2019 & $\begin{array}{c}\mathrm{OAG}^{\mathrm{a}} \text { with } \\
\mathrm{MD}^{\mathrm{g}}-2 /-6 \mathrm{~dB}\end{array}$ & Eye drops LF ${ }^{\mathrm{i}}$ & 3 drops/day & 120 days of treatment & 120 days & $\begin{array}{l}\text { Visual Field improvement } \\
\text { associated to: Increase in PERG } \\
\text { c } \\
\text { P50-N95 and in VEP }{ }^{d} \text { N75-P100 as } \\
\text { e Shortening in PERG }{ }^{\text {c }} \text { P50 and } \\
\text { VEP }^{\text {d P100 Its }}{ }^{\mathrm{f}}\end{array}$ \\
\hline
\end{tabular}


Table 3. Cont.

\begin{tabular}{|c|c|c|c|c|c|c|c|}
\hline Authors & Year & Study Population & Administration & Dosage & Schedule of Treatment & Follow-up & Main Results \\
\hline Parisi V. et al. [90] & 2019 & NAION $^{\mathrm{h}}$ & Oral Solution & $500 \mathrm{~mL} /$ day & $\begin{array}{c}180 \text { days of treatment } \\
\text { followed by } 90 \text { days of } \\
\text { wash-out }\end{array}$ & 270 days & $\begin{array}{l}\text { Visual Field improvement } \\
\text { associated to: Increase in PERG }{ }^{\mathrm{c}} \\
\text { P50-N95 and in VEP }{ }^{\mathrm{d}} \text { N75-P100 as } \\
\text { e Shortening in PERG }{ }^{\mathrm{c}} \text { P50 and } \\
\text { VEP }^{\mathrm{d}} \text { P100 Its }{ }^{\mathrm{f}}\end{array}$ \\
\hline Lanza M. et al. [71] & 2019 & $\mathrm{OAG}^{\mathrm{a}}$ & Oral Solution & $500 \mathrm{mg} /$ day & $\begin{array}{l}2 \text { cycles of } 120 \text { days of } \\
\text { treatment each followed } \\
\text { by } 60 \text { days of wash-out }\end{array}$ & 730 days & $\begin{array}{l}\text { Reduction of Visual Field rate } \\
\text { of progression } \\
\text { Association with slower RNFL-T } \\
\text { and GCC-T }{ }^{\mathrm{m}} \text { thinning }\end{array}$ \\
\hline Rossetti L. et al. [74] & 2020 & $\begin{array}{c}\mathrm{OAG}^{\mathrm{a}} \text { with } \\
\mathrm{MD}^{\mathrm{d}}-2 /-15 \mathrm{~dB}\end{array}$ & Eye drops & 3 drops/day & 1095 days of treatment & 1095 days & $\begin{array}{l}\text { Reduction of Visual Field rate of } \\
\text { progression } \\
\text { Association with slower } \\
\text { RNFL-T }{ }^{1} \text { thinning }\end{array}$ \\
\hline Parravano M. et al. [120] & 2020 & $\mathrm{NPDR}^{\mathrm{n}}$ & Eye drops & 3 drops/day & 1095 days of treatment & 1095 days & $\begin{array}{l}\text { Increase in FDT }{ }^{\mathrm{o}} 10-2 \text { Macular } \\
\text { Sensitivity, } \\
\text { Association with IPL } \mathrm{p} \text { and OPL } \mathrm{q} \\
\text { thickness stabilization } \\
\text { Foveal vessel density at SCP }{ }^{\mathrm{r}} \text { and } \\
\text { DCP }^{\mathrm{s}} \text { stabilization at OCTA }\end{array}$ \\
\hline
\end{tabular}

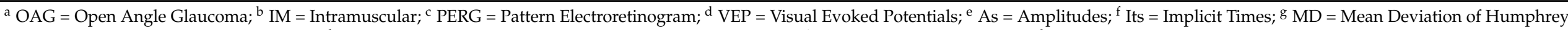

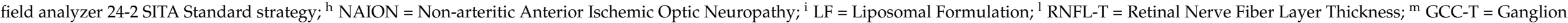

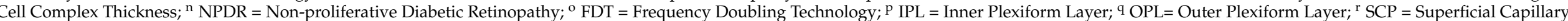
Plexus; ${ }^{s}$ DCP $=$ Deep Capillary Plexus; ${ }^{t}$ OCTA $=$ Optical Coherence Tomography Angiography 


\subsubsection{Psychophysical Evidences}

By looking at the results in details, in the long term, Humphrey Matrix FDT 24-2 mean sensitivity (MS), PSD, and MD between the DC and DP groups appeared to be similar, whereas a significant difference of FDT 10-2 MS was detected between the two groups. In particular, a significant decrease of 10-2 MS in the DP group over time was found in comparison with the DC group, where no significant changes were observed during the follow up [120]. The reduction of MS may be related to both a higher susceptibility of the magno-cellular RGCs to hyperglycemia or lower redundancy of those cells among the entire RGCs, as already reported by Parravano et al., who reported an early functional impairment of RGCs through FDT in the eyes of the patients with DM1 [121].

\subsubsection{Morphological Evidences}

By analyzing the morphological results, OCT parafoveal Inner Nuclear Layer (INL) thickness showed a significant increase the DP group over time in comparison with the DC group, where no significant changes were noted. Moreover, the Outer Plexiform Layer (OPL) thickness showed a significant reduction at 12, 24, and 36 months in the DP group, while the OPL values were similar over the entire follow up in the DC group [120]. A specific change of the retinal layers in DR, with the progressive increase in INL and decrease in OPL thickness, could indicate the activation of the glia and the Muller cells and the induction of subclinical macular edema, as early biomarkers of the development of the disease $[122,123]$. The microvascular evaluation that was obtained with OCTA showed that the foveal vessel density (VD) at superficial capillary plexus (SCP) and that at deep capillary plexus (DCP) were different between the DC and DP groups; in particular, the foveal VD at both SCP and DCP appeared to be reduced over time in the DP group in comparison with DC group, where no significant changes were observed. In addition, the area of the foveal avascular zone (FAZ) showed no significant changes over time in both groups. As already reported, the impairment of DCP represents a biomarker for both early diagnosis and risk of progression in DR [124].

With regard to the $\mathrm{AO}$ findings, the cone density, linear dispersion index, and heterogeneity packing index showed no significant changes between the DC and DP groups over time. In diabetic patients with DR, an interesting model to evaluate the neurodegenerative process is to assess the corneal innervation by means of in vivo confocal biomicroscopy of corneal sub-basal plexus [125]. A recent randomized clinical trial was performed on diabetic patients with DR randomized to receive citicoline and vitamin B12 eye drops (OMK2 ${ }^{\circledR}, 3$ drops/day) or placebo for 18 months, with the aim to evaluate the effect on corneal morphology (with confocal microscopy) and sensitivity (by corneal esthesiometry). In the group that was treated with citicoline, a significant increase of corneal nerve fiber length density and corneal sensitivity was detected with respect to those that were observed in the group treated with placebo [126]. 
Table 4. Summary of clinical studies evaluating the effects of Citicoline in human ophthalmological neurodegenerative disease: morphological evidences.

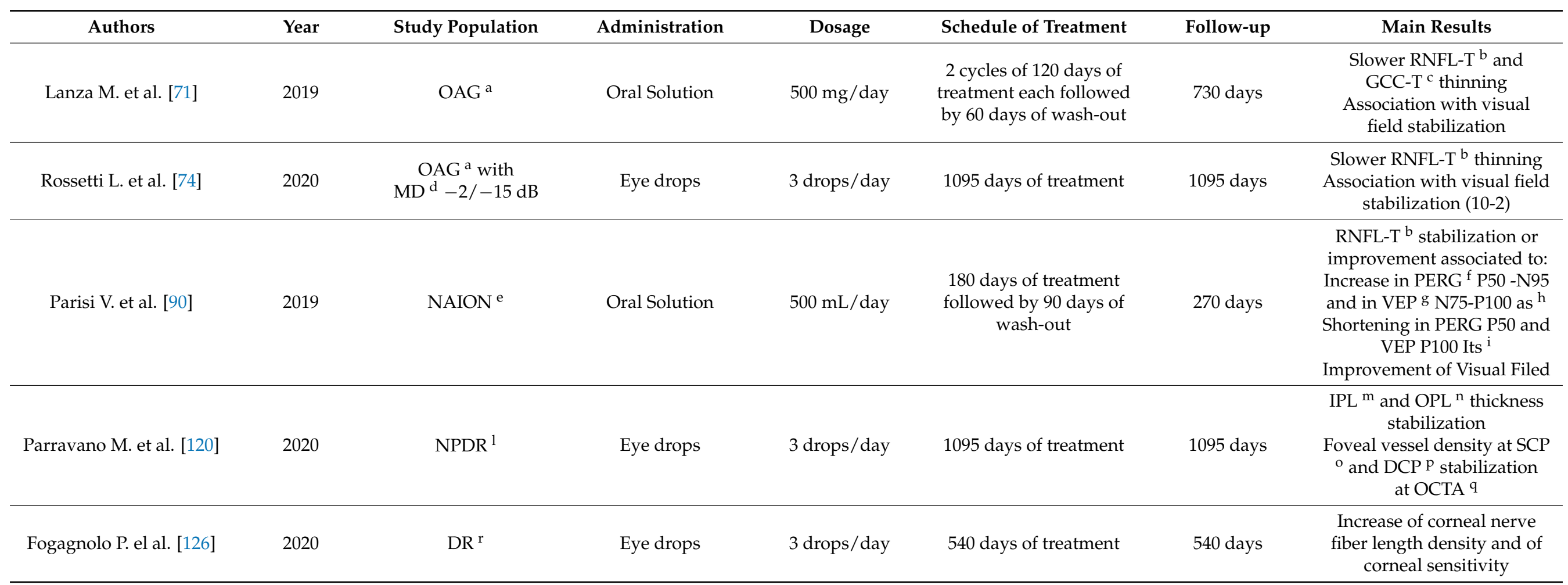

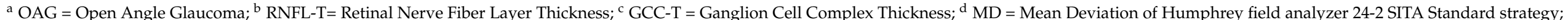

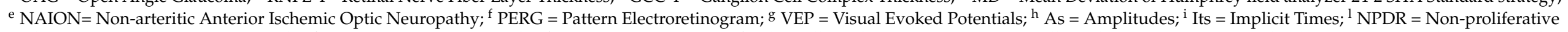

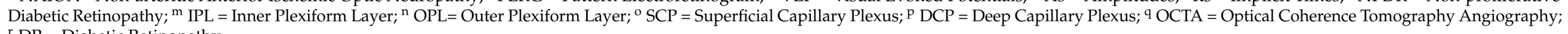

${ }^{\mathrm{r}} \mathrm{DR}=$ Diabetic Retinopathy. 


\subsubsection{Electrofunctional Evidences}

At this moment, there is a lack of information regarding the possible effects of citicoline on the function of RGCs or of the retinal pre-ganglionic elements on patients with DM1 and mild signs of NPDR, as assessed by Patter-ERG and multifocal ERG, respectively.

\section{Concluding Remarks}

The rationale for the use of citicoline in ophthalmological neurodegenerative diseases is founded on its multifactorial mechanism of action and the involvement in several metabolic pathways including phospholipid homeostasis, mitochondrial dynamics as well as cholinergic and dopaminergic transmission, as reported in several pre-clinical studies. In addition, recent insights suggest an involvement of citicoline in the regulation of the intracellular proteostasis network through an interaction with the proteasome.

Nevertheless, besides strong knowledge supporting its mechanisms of action, strong clinical evidences are required for an evidence-based clinical use of any compound.

In addition to the evidences of an improvement of psychophysical, morphological, and electrophysiological outcomes, coming from small comparative randomized pilot clinical trials or larger not controlled before-after studies (performed in different ophthalmological neurodegenerative diseases, like OAG, AION, and DR), for the first time a reduction of the rate of visual field progression has been recently reported in OAG patients in a large randomized double-masked placebo-controlled clinical trial, thus further supporting the clinical use of citicoline.

Author Contributions: Conceptualization: F.O. and V.P.; Methodology: V.P., F.O., L.R. and G.M.; Data collection: M.P., G.R., L.Z., D.S., D.R. and C.C.; Interpretation of data: V.P., F.O., D.S., L.R. and G.M.; Writing—original draft preparation: V.P., F.O., L.R., G.M., M.P., G.R., L.Z., D.S., M.C., D.R. and C.C.; Critical revision for important intellectual content: V.P., F.O., L.R. and G.M.; Final approval of the version to be published: F.O. and V.P. All authors have read and agreed to the published version of the manuscript.

Funding: This work received no external funding.

Institutional Review Board Statement: Not applicable.

Informed Consent Statement: Not applicable.

Data Availability Statement: No new data were created or analyzed in this study. Data sharing is not applicable to this article.

Acknowledgments: The contribution of IRCCS Fondazione Bietti to this work was supported by the Italian Ministry of Health and by Fondazione Roma.

Conflicts of Interest: Oddone F: speaker's fees from Allergan, Santen, Omikron Italia; Rossetti L: speaker's fees, grants and consultancy from Omikron Italia; Parravano M: personal fees from Allegan, Novartis, Bayer, Zeiss, Omikron Italia; Sbardella D: none; Ziccardi L: none; Roberti G: none; Carnevale C: none; Romano D: none; Manni G: speaker's fees from Omikron Italia; Parisi V: speaker's fees from Omikron Italia.

$\begin{array}{ll}\text { Abbreviations } \\ \text { RGCs } & \text { retinal ganglion cells } \\ \text { ONH } & \text { optic nerve head } \\ \text { OAG } & \text { open angle glaucoma } \\ \text { AION } & \text { anterior ischemic optic neuropathy } \\ \text { DR } & \text { diabetic retinopathy } \\ \text { KA } & \text { kainic acid } \\ \text { MAPK } & \text { Mitogen Activated Protein Kinase } \\ \text { TNF- } \alpha & \text { Tumor Necrosis Factor } \alpha \\ \text { RNFL } & \text { retinal nerve fiber layer } \\ \text { IPL } & \text { inner plexiform layer }\end{array}$




$\begin{array}{ll}\text { PLA2 } & \text { phospholipase A2 } \\ \text { PN } & \text { proteostasis network } \\ \text { UPS } & \text { ubiquitin proteasome system } \\ \text { CamKII } & \text { calmodulin kinase pathways } \\ \text { PKA } & \text { Protein Kinase A } \\ \text { IOP } & \text { intraocular pressure } \\ \text { NPA } & \text { non-perception area } \\ \text { HFA } & \text { Humphrey field analyzer } \\ \text { RoP } & \text { rate of progression } \\ \text { MD } & \text { mean deviation } \\ \text { PSD } & \text { pattern standard deviation } \\ \text { OCT } & \text { optical coherence tomography } \\ \text { PERG } & \text { pattern electroretinogram } \\ \text { VEP } & \text { visual evoked potential } \\ \text { RCT } & \text { retinocortical time } \\ \text { NAION } & \text { non-arteritic anterior ischemic optic neuropathy } \\ \text { AAION } & \text { arteritic anterior ischemic optic neuropathy } \\ \text { VA } & \text { Visual Acuity } \\ \text { Sd-OCT } & \text { spectral domain optical coherence tomography } \\ \text { RNFL-T } & \text { RNFL thickness } \\ \text { DM1 } & \text { type 1 diabetes mellitus } \\ \text { NPDR } & \text { non-proliferative diabetic retinopathy } \\ \text { FDT } & \text { frequency doubling technology } \\ \text { OCTA } & \text { OCT angiography } \\ \text { AO } & \text { adaptive optics } \\ \text { MS } & \text { mean sensitivity } \\ \text { INL } & \text { inner nuclear layer } \\ \text { OPL } & \text { outer plexiform layer } \\ \text { VD } & \text { vessel density } \\ \text { SCP } & \text { superficial capillary plexus } \\ \text { DCP } & \text { deep capillary plexus } \\ \text { FAZ } & \text { foveal avascular zone } \\ & \end{array}$

\section{References}

1. Sadun, A.A.; Glaser, J.S. Anatomy of the visual sensory system. In Neuro-Ophthalmology, 3rd ed.; Glaser, J.S., Ed.; Lippincott Williams and Wilkins: Philadelphia, PA, USA, 1999; Volume 4, pp. 75-94.

2. Chang, E.E.; Goldberg, J.L. Glaucoma 2.0: Neuroprotection, neuroregeneration, neuroenhancement. Ophthalmology 2012, 119, 979-986. [CrossRef] [PubMed]

3. Deng, S.; Wang, M.; Yan, Z.; Tian, Z.; Chen, H.; Yang, X.; Zhuo, Y. Autophagy in retinal ganglion cells in a rhesus monkey chronic hypertensive glaucoma model. PLoS ONE 2013, 15, e77100. [CrossRef] [PubMed]

4. Guo, L.; Salt, T.E.; Luong, V.; Wood, N.; Cheung, W.; Maass, A.; Ferrari, G.; Russo-Marie, F.; Sillito, A.M.; Cheetham, M.E.; et al. Targeting amyloid-beta in glaucoma treatment. Proc. Natl. Acad. Sci. USA 2007, 104, 13444-13449. [CrossRef]

5. Romano, G.L.; Amato, R.; Lazzara, F.; Porciatti, V.; Chou, T.H.; Drago, F.; Bucolo, C. P2X7 receptor antagonism preserves retinal ganglion cells in glaucomatous mice. Biochem. Pharmacol. 2020, 180, 114199. [CrossRef]

6. Khalilpour, S.; Latifi, S.; Behnammanesh, G.; Majid, A.M.S.A.; Majid, A.S.A.; Tamayol, A. Ischemic optic neuropathy as a model of neurodegenerative disorder: A review of pathogenic mechanism of axonal degeneration and the role of neuroprotection. $J$. Neurol. Sci. 2017, 375, 430-441. [CrossRef] [PubMed]

7. Simó, R.; Stitt, A.W.; Gardner, T.W. Neurodegeneration in diabetic retinopathy: Does it really matter? Diabetologia 2018, 61, 1902-1912. [CrossRef]

8. $\quad$ Tang, Z.; Chan, M.Y.; Leung, W.Y.; Wong, H.Y.; Ng, C.M.; Chan, V.T.T.; Wong, R.; Lok, J.; Szeto, S.; Chan, J.C.K.; et al. Assessment of retinal neurodegeneration with spectral-domain optical coherence tomography: A systematic review and meta-analysis. Eye 2020, 24, 1-9. [CrossRef]

9. Simó, R.; Hernández, C.; European Consortium for the Early Treatment of Diabetic Retinopathy (EUROCONDOR). Neurodegeneration is an early event in diabetic retinopathy: Therapeutic implications. Br. J. Ophthalmol. 2012, 96, 1285-1290. [CrossRef] [PubMed]

10. Roberti, G.; Tanga, L.; Michelessi, M.; Quaranta, L.; Parisi, V.; Manni, G.; Oddone, F. Cytidine 5'-Diphosphocholine (Citicoline) in Glaucoma: Rationale of Its Use, Current Evidence and Future Perspectives. Int. J. Mol. Sci. 2015, 16, 28401-28417. [CrossRef]

11. Romano, G.L.; Platania, C.B.; Forte, S.; Salomone, S.; Drago, F.; Bucolo, C. MicroRNAtarget prediction in glaucoma. Prog. Brain Res. 2015, 220, 217-240. [PubMed] 
12. Rejdak, R.; Toczolowski, J.; Solski, J.; Duma, D.; Grieb, P. Citicoline Treatment Increases Retinal Dopamine Content in Rabbits. Ophthalmic. Res. 2002, 34, 146-149. [CrossRef]

13. Martinet, M.; Fonlupt, P.; Pacheco, H. Effects of Cytidine-5' Diphosphocholine on Norepinephrine, Dopamine and Serotonin Synthesis in Various Regions of the Rat Brain. Arch. Int. Pharmacodyn. Ther. 1979, 239, 52-61. [PubMed]

14. Bucolo, C.; Leggio, G.M.; Drago, F.; Salomone, S. Dopamine outside the brain: The eye, cardiovascular system and endocrine pancreas. Pharmacol Ther. 2019, 203, 107392. [CrossRef]

15. Faiq, M.A.; Wollstein, G.; Schuman, J.S.; Chan, K.C. Cholinergic nervous system and glaucoma: From basic science to clinical applications. Prog. Retin. Eye Res. 2019, 72, 100767. [CrossRef] [PubMed]

16. Grieb, P. Neuroprotective Properties of Citicoline: Facts, Doubts and Unresolved Issues. CNS Drugs 2014, 28, 185-193. [CrossRef] [PubMed]

17. Kennedy, E.P.; Weiss, S.B. The function of cytidine coenzymes in the biosynthesis of phospholipides. J. Biol. Chem. 1956, 222, 193-214. [CrossRef]

18. Trovarelli, G.; de Medio, G.E.; Dorman, R.V.; Piccinin, G.L.; Horrocks, L.A.; Porcellati, G. Effect of cytidine diphosphate choline (CDP-choline) on ischemia-induced alterations of brain lipid in the gerbil. Neurochem. Res. 1981, 6, 821-833. [CrossRef]

19. Fagone, P.; Jackowski, S. Phosphatidylcholine and the CDP-choline cycle. Biochim. Biophys. Acta 2013, 1831, 523-532. [CrossRef] [PubMed]

20. Weiss, G.B. Metabolism and actions of CDP-choline as an endogenous compound and administered exogenously as citicoline. Life Sci. 1995, 56, 637-660. [CrossRef]

21. Gandolfi, S.; Marchini, G.; Caporossi, A.; Scuderi, G.; Tomasso, L.; Brunoro, A. Cytidine 5'-Diphosphocholine (Citicoline): Evidence for a Neuroprotective Role in Glaucoma. Nutrients 2020, 12, 793. [CrossRef]

22. Grieb, P.; Rejdak, R. Pharmacodynamics of citicoline relevant to the treatment of glaucoma. J. Neurosci. Res. 2002, 67, 143-148. [CrossRef]

23. Secades, J.J. Citicoline: Pharmacological and clinical review, 2016 update. Rev. Neurol. 2016, 63, 1-73.

24. Schauss, A.G.; Somfai-Relle, S.; Financsek, I.; Glavits, R.; Parent, S.C.; Endres, J.R.; Varga, T.; Szücs, Z.; Clewell, A. Single- and Repeated-Dose Oral Toxicity Studies of Citicoline Free-Base (Choline Cytidine 5'-Pyrophosphate) in Sprague-Dawley Rats. Int. J. Toxicol. 2009, 28, 479-487. [CrossRef]

25. Gareri, P.; Castagna, A.; Cotroneo, A.M.; Putignano, S.; De Sarro, G.; Bruni, A.C. The Role of Citicoline in Cognitive Impairment: Pharmacological Characteristics, Possible Advantages, and Doubts for an Old Drug with New Perspectives. Clin. Interv. Aging 2015, 10, 1421-1429. [CrossRef]

26. Carnevale, C.; Manni, G.; Roberti, G.; Micera, A.; Bruno, L.; Cacciamani, A.; Altafini, R.; Quaranta, L.; Agnifili, L.; Tanga, L.; et al. Human Vitreous Concentrations of Citicoline Following Topical Application of Citicoline 2\% Ophthalmic Solution. PLoS ONE 2019, 14, e0224982. [CrossRef]

27. Matteucci, A.; Varano, M.; Gaddini, L.; Mallozzi, C.; Villa, M.; Pricci, F.; Malchiodi-Albedi, F. Neuroprotective Effects of Citicoline in in Vitro Models of Retinal Neurodegeneration. Int. J. Mol. Sci. 2014, 15, 6286-6297. [CrossRef]

28. Hurtado, O.; Pradillo, J.M.; Fernández-López, D.; Morales, J.R.; Sobrino, T.; Castillo, J.; Alborch, E.; Moro, M.A.; Lizasoain, I. Delayed Post-Ischemic Administration of CDP-Choline Increases EAAT2 Association to Lipid Rafts and Affords Neuroprotection in Experimental Stroke. Neurobiol. Dis. 2008, 29, 123-131. [CrossRef]

29. Park, C.H.; Kim, Y.S.; Noh, H.S.; Cheon, E.W.; Yang, Y.A.; Yoo, J.M.; Choi, W.S.; Cho, G.J. Neuroprotective Effect of Citicoline against KA-Induced Neurotoxicity in the Rat Retina. Exp. Eye Res. 2005, 81, 350-358. [CrossRef]

30. Oshitari, T.; Fujimoto, N.; Adachi-Usami, E. Citicoline Has a Protective Effect on Damaged Retinal Ganglion Cells in Mouse Culture Retina. Neuroreport 2002, 13, 2109-2111. [CrossRef] [PubMed]

31. Oshitari, T.; Yoshida-Hata, N.; Yamamoto, S. Effect of neurotrophic factors on neuronal apoptosis and neurite regeneration in cultured rat retinas exposed to high glucose. Brain Res. 2010, 1346, 43-51. [CrossRef] [PubMed]

32. Matteucci, A.; Gaddini, L.; Villa, M.; Varano, M.; Parravano, M.; Monteleone, V.; Cavallo, F.; Leo, L.; Mallozzi, C.; MalchiodiAlbedi, F.; et al. Neuroprotection by Rat Müller Glia against High Glucose-Induced Neurodegeneration through a Mechanism Involving ERK1/2 Activation. Exp. Eye Res. 2014, 125, 20-29. [CrossRef] [PubMed]

33. Davinelli, S.; Chiosi, F.; Di Marco, R.; Costagliola, C.; Scapagnini, G. Cytoprotective Effects of Citicoline and Homotaurine against Glutamate and High Glucose Neurotoxicity in Primary Cultured Retinal Cells. Oxid. Med. Cell Longev. 2017, 2017, 2825703. [CrossRef] [PubMed]

34. Bogdanov, P.; Sampedro, J.; Solà-Adell, C.; Simó-Servat, O.; Russo, C.; Varela-Sende, L.; Simó, R.; Hernández, C. Effects of Liposomal Formulation of Citicoline in Experimental Diabetes-Induced Retinal Neurodegeneration. Int. J. Mol. Sci. 2018, 19, 2458. [CrossRef]

35. Krupinski, J.; Slevin, M.; Badimon, L. Citicoline Inhibits MAP Kinase Signalling Pathways after Focal Cerebral Ischaemia. Neurochem. Res. 2005, 30, 1067-1073. [CrossRef] [PubMed]

36. Maestroni, S.; Preziosa, C.; Capuano, V.; Spinello, A.; Zucchiatti, I.; Gabellini, D.; Lattanzio, R.; Bandello, F.; Zerbini, G. In vivo Evaluation of Retinal and Choroidal Structure in a Mouse Model of Long-Lasting Diabetes. Effect of Topical Treatment with Citicoline. J. Ocul. Dis. Ther. 2015, 3, 1-8. 
37. Krupinski, J.; Ferrer, I.; Barrachina, M.; Secades, J.J.; Mercadal, J.; Lozano, R. CDP-Choline Reduces pro-Caspase and Cleaved Caspase-3 Expression, Nuclear DNA Fragmentation, and Specific PARP-Cleaved Products of Caspase Activation Following Middle Cerebral Artery Occlusion in the Rat. Neuropharmacology 2002, 42, 846-854. [CrossRef]

38. Hurtado, O.; Hernández-Jiménez, M.; Zarruk, J.G.; Cuartero, M.I.; Ballesteros, I.; Camarero, G.; Moraga, A.; Pradillo, J.M.; Moro, M.A.; Lizasoain, I. Citicoline (CDP-Choline) Increases Sirtuin1 Expression Concomitant to Neuroprotection in Experimental Stroke. J. Neurochem. 2013, 126, 819-826. [CrossRef]

39. Adibhatla, R.M.; Hatcher, J.F. Citicoline Decreases Phospholipase A2 Stimulation and Hydroxyl Radical Generation in Transient Cerebral Ischemia. J. Neurosci. Res. 2003, 73, 308-315. [CrossRef]

40. Giménez, R.; Aguilar, J. Effects of CDP-Choline Administration on Brain Striatum Platelet-Activating Factor in Aging Rats. Eur. J. Pharmacol. 1998, 344, 149-152. [CrossRef]

41. Paradies, G.; Paradies, V.; Ruggiero, F.M.; Petrosillo, G. Role of Cardiolipin in Mitochondrial Function and Dynamics in Health and Disease: Molecular and Pharmacological Aspects. Cells 2019, 8, 728. [CrossRef]

42. Schuettauf, F.; Rejdak, R.; Thaler, S.; Bolz, S.; Lehaci, C.; Mankowska, A.; Zarnowski, T.; Junemann, A.; Zagorski, Z.; Zrenner, E.; et al. Citicoline and Lithium Rescue Retinal Ganglion Cells Following Partial Optic Nerve Crush in the Rat. Exp. Eye Res. 2006, 83, 1128-1134. [CrossRef]

43. Brailoiu, E.; Chakraborty, S.; Brailoiu, G.C.; Zhao, P.; Barr, J.L.; Ilies, M.A.; Unterwald, E.M.; Abood, M.E.; Taylor, C.W. Choline Is an Intracellular Messenger Linking Extracellular Stimuli to $\mathrm{IP}_{3}$-Evoked $\mathrm{Ca}^{2+}$ Signals through Sigma-1 Receptors. Cell Rep. 2019, 26, 330-337. [CrossRef] [PubMed]

44. Bucolo, C.; Campana, G.; Di Toro, R.; Cacciaguerra, S.; Spampinato, S. Sigma1 recognition sites in rabbit iris-ciliary body: Topical sigma1-site agonists lower intraocular pressure. J. Pharmacol. Exp. Ther. 1999, 289, 1362-1369.

45. Bucolo, C.; Drago, F.; Lin, L.R.; Reddy, V.N. Sigma receptor ligands protect human retinal cells against oxidative stress. Neuroreport 2006, 27, 287-291. [CrossRef]

46. Mir, C.; Clotet, J.; Aledo, R.; Durany, N.; Argemí, J.; Lozano, R.; Cervós-Navarro, J.; Casals, N. CDP-Choline Prevents GlutamateMediated Cell Death in Cerebellar Granule Neurons. J. Mol. Neurosci. MN 2003, 20, 53-60. [CrossRef]

47. Hipp, M.S.; Kasturi, P.; Hartl, F.U. The Proteostasis Network and Its Decline in Ageing. Nat. Rev. Mol. Cell Biol. 2019, 20, 421-435. [CrossRef]

48. Newton, T.M.; Duce, J.A.; Bayle, E.D. The Proteostasis Network Provides Targets for Neurodegeneration. Br. J. Pharmacol. 2019, 176, 3508-3514. [CrossRef]

49. Lopez Salon, M.; Pasquini, L.; Besio Moreno, M.; Pasquini, J.M.; Soto, E. Relationship between Beta-Amyloid Degradation and the 26S Proteasome in Neural Cells. Exp. Neurol. 2003, 180, 131-143. [CrossRef]

50. Tundo, G.R.; Sbardella, D.; Ciaccio, C.; Grasso, G.; Gioia, M.; Coletta, A.; Polticelli, F.; Di Pierro, D.; Milardi, D.; Van Endert, P.; et al. Multiple Functions of Insulin-Degrading Enzyme: A Metabolic Crosslight? Crit. Rev. Biochem. Mol. Biol. 2017, 52, 554-582. [CrossRef] [PubMed]

51. Sbardella, D.; Tundo, G.R.; Coletta, A.; Marcoux, J.; Koufogeorgou, E.I.; Ciaccio, C.; Santoro, A.M.; Milardi, D.; Grasso, G.; Cozza, P.; et al. The Insulin-Degrading Enzyme Is an Allosteric Modulator of the 20S Proteasome and a Potential Competitor of the 19S. Cell Mol. Life Sci. CMLS 2018, 75, 3441-3456. [CrossRef]

52. Sbardella, D.; Tundo, G.R.; Sciandra, F.; Bozzi, M.; Gioia, M.; Ciaccio, C.; Tarantino, U.; Brancaccio, A.; Coletta, M.; Marini, S. Proteasome Activity Is Affected by Fluctuations in Insulin-Degrading Enzyme Distribution. PLoS ONE 2015, 10, e0132455. [CrossRef]

53. Ciechanover, A.; Brundin, P. The Ubiquitin Proteasome System in Neurodegenerative Diseases: Sometimes the Chicken, Sometimes the Egg. Neuron 2003, 40, 427-446. [CrossRef]

54. Campello, L.; Esteve-Rudd, J.; Cuenca, N.; Martín-Nieto, J. The Ubiquitin-Proteasome System in Retinal Health and Disease. Mol. Neurobiol. 2013, 47, 790-810. [CrossRef] [PubMed]

55. Tundo, G.R.; Sbardella, D.; Santoro, A.M.; Coletta, A.; Oddone, F.; Grasso, G.; Milardi, D.; Lacal, P.M.; Marini, S.; Purrello, R.; et al. The Proteasome as a Druggable Target with Multiple Therapeutic Potentialities: Cutting and Non-Cutting Edges. Pharmacol. Ther. 2020, 213, 107579. [CrossRef]

56. Sbardella, D.; Coletta, A.; Tundo, G.R.; Ahmed, I.M.M.; Bellia, F.; Oddone, F.; Manni, G.; Coletta, M. Structural and Functional Evidence for Citicoline Binding and Modulation of 20S Proteasome Activity: Novel Insights into Its pro-Proteostatic Effect. Biochem. Pharmacol. 2020, 177, 113977. [CrossRef]

57. Alvarez, X.A.; Sampedro, C.; Lozano, R.; Cacabelos, R. Citicoline Protects Hippocampal Neurons against Apoptosis Induced by Brain Beta-Amyloid Deposits plus Cerebral Hypoperfusion in Rats. Methods Find Exp. Clin. Pharmacol. 1999, 21, 535-540. [CrossRef]

58. Glick, D.; Barth, S.; Macleod, K.F. Autophagy: Cellular and molecular mechanisms. J. Pathol. 2010, 221, 3-12. [CrossRef]

59. Livneh, I.; Cohen-Kaplan, V.; Cohen-Rosenzweig, C.; Avni, N.; Ciechanover, A. The Life Cycle of the 26S Proteasome: From Birth, through Regulation and Function, and onto Its Death. Cell Res. 2016, 26, 869-885. [CrossRef]

60. VerPlank, J.J.S.; Goldberg, A.L. Regulating Protein Breakdown through Proteasome Phosphorylation. Biochem. J. 2017, 474, 3355-3371. [CrossRef] 
61. Flaxman, S.R.; Bourne, R.R.A.; Resnikoff, S.; Ackland, P.; Braithwaite, T.; Cicinelli, M.V.; Das, A.; Jonas, J.B.; Keeffe, J.; Kempen, J.H.; et al. Global causes of blindness and distance vision impairment 1990-2020: A systematic review and meta-analysis. Lancet Glob. Health 2017, 5, e1221-e1234. [CrossRef]

62. Quigley, H.A. Number of people with glaucoma worldwide. Br. J. Ophthalmol. 1996, 80, 389-393. [CrossRef]

63. Leske, M.C.; Heijl, A.; Hyman, L.; Bengtsson, B. Early Manifest Glaucoma Trial: Design and baseline data. Ophthalmology 1999, 106, 2144-2153. [CrossRef]

64. Bucolo, C.; Platania, C.B.M.; Drago, F.; Bonfiglio, V.; Reibaldi, M.; Avitabile, T.; Uva, M. Novel Therapeutics in Glaucoma Management. Curr. Neuropharmacol. 2018, 16, 978-992. [CrossRef]

65. Pecori Giraldi, J.; Virno, M.; Covelli, G.; Grechi, G.; De Gregorio, F. Therapeutic value of citicoline in the treatment of glaucoma (computerized and automated perimetric investigation). Int. Ophthalmol. 1989, 13, 109-112. [CrossRef]

66. Virno, M.; Pecori-Giraldi, J.; Liguori, A.; De Gregorio, F. The protective effect of citicoline on the progression of the perimetric defects in glaucomatous patients (perimetric study with a 10-year follow-up). Acta Ophthalmol. Scand. Suppl. 2000, $232,56-57$. [CrossRef]

67. Ventura, L.; Porciatti, V. Restoration of retinal ganglion cell function in early glaucoma after intraocular pressure reduction. Ophthalmology 2005, 1, 20-27. [CrossRef] [PubMed]

68. Ottobelli, L.; Manni, G.L.; Centofanti, M.; Iester, M.; Allevena, F.; Rossetti, L. Citicoline oral solution in glaucoma: Is there a role in slowing disease progression? Ophthalmologica 2013, 229, 219-226. [CrossRef] [PubMed]

69. Agut, J.; Font, E.; Sacristán, A.; Ortiz, J.A. Bioavailability of methyl-14C CDP-choline by oral route. Arzneimittelforschung 1983, 33, 1045-1047. [PubMed]

70. Roda, A.; Fini, A.; Grigolo, B.; Scapini, G. Routes of administration and serum levels of [Methyl-14C]-Cytidine-Diphosphocholine. Curr. Ther. Res. Clin. Exp. 1983, 34, 1049-1053.

71. Lanza, M.; Gironi Carnevale, U.A.; Mele, L.; Bifani Sconocchia, M.; Bartollino, S.; Costagliola, C. Morphological and Functional Evaluation of Oral Citicoline Therapy in Chronic Open-Angle Glaucoma Patients: A Pilot Study with a 2-Year Follow-Up. Front. Pharmacol. 2019, 10, 1117. [CrossRef]

72. Roberti, G.; Tanga, L.; Parisi, V.; Sampalmieri, M.; Centofanti, M.; Manni, G. A preliminary study of the neuroprotective role of citicoline eye drops in glaucomatous optic neuropathy. Indian J. Ophthalmol. 2014, 62, 549-553. [CrossRef]

73. Parisi, V.; Centofanti, M.; Ziccardi, L.; Tanga, L.; Michelessi, M.; Roberti, G.; Manni, G. Treatment with citicoline eye drops enhances retinal function and neural conduction along the visual pathways in open angle glaucoma. Graefes Arch. Clin. Exp. Ophthalmol. 2015, 253, 1327-1340. [CrossRef]

74. Rossetti, L.; Iester, M.; Tranchina, L.; Ottobelli, L.; Coco, G.; Calcatelli, E.; Ancona, C.; Cirafici, P.; Manni, G. Can Treatment With Citicoline Eyedrops Reduce Progression in Glaucoma? The Results of a Randomized Placebo-controlled Clinical Trial. J. Glaucoma 2020, 29, 513-520. [CrossRef] [PubMed]

75. Mafei, L.; Fiorentini, A. Electroretinographic responses to alternating gratings before and after section of the optic nerve. Science 1981, 211, 953-955. [CrossRef]

76. Parisi, V. Impaired visual function in glaucoma. Clin. Neurophysiol. 2001, 112, 351-358. [CrossRef]

77. Parisi, V.; Scarale, M.E.; Balducci, N.; Fresina, M.; Campos, E.C. Electrophysiological detection of delayed postretinal neural conduction in human amblyopia. Investig. Ophthalmol. Vis. Sci. 2010, 51, 5041-5048. [CrossRef]

78. Ziccardi, L.; Sadun, F.; De Negri, A.M.; Barboni, P.; Savini, G.; Borrelli, E.; La Morgia, C.; Carelli, V.; Parisi, V. Retinal function and neural conduction along the visual pathways in affected and unaffected carriers with Leber's hereditary optic neuropathy. Investig. Ophthalmol. Vis. Sci. 2013, 54, 6893-6901. [CrossRef]

79. Celesia, G.G.; Kaufman, D.; Cone, S.B. Simultaneous recording of pattern electroretinography and visual evoked potentials in multiple sclerosis. A method to separate demyelination from axonal damage to the optic nerve. Arch. Neurol. 1986, 43, 1247-1252. [CrossRef]

80. Parisi, V.; Manni, G.; Colacino, G.; Bucci, M.G. Cytidine-5'-diphosphocholine (citicoline) improves retinal and cortical responses in patients with glaucoma. Ophthalmology 1999, 106, 1126-1134. [CrossRef]

81. Cacabelos, R.; Caamaño, J.; Gómez, M.J.; Fernández-Novoa, L.; Franco-Maside, A.; Alvarez, X.A. Therapeutic effects of CDPcholine in Alzheimer's disease. Cognition, brain mapping, cerebrovascular hemodynamics, and immune factors. Ann. N. Y. Acad. Sci. 1996, 777, 399-403. [CrossRef]

82. Parisi, V. Electrophysiological assessment of glaucomatous visual dysfunction during treatment with cytidine-5'-diphosphocholine (citicoline): A study of 8 years of follow-up. Doc. Ophthalmol. 2005, 110, 91-102. [CrossRef]

83. Rejdak, R.; Toczolowski, J.; Kurkowski, J.; Kaminski, M.L.; Rejdak, K.; Stelmasiak, Z.; Grieb, P. Oral citicoline treatment improves visual pathway function in glaucoma. Med. Sci. Monit. 2003, 9, PI24-PI28.

84. Parisi, V.; Coppola, G.; Centofanti, M.; Oddone, F.; Angrisani, A.M.; Ziccardi, L.; Ricci, B.; Quaranta, L.; Manni, G. Evidence of the neuroprotective role of citicoline in glaucoma patients. Prog. Brain Res. 2008, 173, 541-554.

85. Parisi, V.; Oddone, F.; Roberti, G.; Tanga, L.; Carnevale, C.; Ziccardi, L.; Manni, G. Enhancement of Retinal Function and of Neural Conduction Along the Visual Pathway Induced by Treatment with Citicoline Eye Drops in Liposomal Formulation in Open Angle Glaucoma: A Pilot Electrofunctional Study. Adv. Ther. 2019, 36, 987-996. [CrossRef] [PubMed]

86. Hayreh, S.S. Ischemic optic neuropathy. Prog. Retin. Eye Res. 2009, 28, 34-62. [CrossRef] [PubMed]

87. Newman, N.J. Optic neuropathy. Neurology 1996, 46, 315-322. [CrossRef] 
88. Hayreh, S.S. Controversies on neuroprotection therapy in non-arteritic anterior ischaemic optic neuropathy. Br. J. Ophthalmol. 2020, 104, 153-156. [CrossRef]

89. Parisi, V.; Coppola, G.; Ziccardi, L.; Gallinaro, G.; Falsini, B. Cytidine-5'-diphosphocholine (Citicoline): A pilot study in patients with non-arteritic ischaemic optic neuropathy. Eur. J. Neurol. 2008, 15, 465-474. [CrossRef] [PubMed]

90. Parisi, V.; Barbano, L.; Di Renzo, A.; Coppola, G.; Ziccardi, L. Neuroenhancement and neuroprotection by oral solution citicoline in nonarteritic ischemic optic neuropathy as a model of neurodegeneration: A randomized pilot study. PLoS ONE 2019, 14, e0220435. [CrossRef] [PubMed]

91. Hayreh, S.S.; Zimmerman, B. Non-arteritic anterior ischemic optic neuropathy: Natural history of visual outcome. Ophthalmology 2008, 115, 298-305. [CrossRef] [PubMed]

92. Aggarwal, D.O.; Huang, D.; Sadun, A.A. Patterns of ganglion cell complex and nerve fiber layer loss in nonarteritic ischemic optic neuropathy by Fourier-domain optical coherence tomography. Investig. Ophthalmol. Vis. Sci. 2012, 53, 4539-4545. [CrossRef]

93. Barbano, L.; Ziccardi, L.; Parisi, V. Correlations between visual morphological, electrophysiological, and acuity changes in chronic non-arteritic ischemic optic neuropathy. Graefes Arch. Clin. Exp. Ophthalmol. 2021. [CrossRef]

94. Bellusci, C.; Savini, G.; Carbonelli, M.; Carelli, V.; Sadun, A.A.; Barboni, P. Retinal nerve fiber layer thickness in nonarteritic anterior ischemic optic neuropathy: OCT characterization of the acute and resolving phases. Graefes Arch. Clin. Exp. Ophthalmol. 2008, 246, 641-647. [CrossRef]

95. Akbari, M.; Abdi, P.; Fard, M.A.; Afzali, M.; Ameri, A.; Yazdani-Abyaneh, A.; Mohammadi, M.; Moghimi, S. Retinal Ganglion Cell Loss Precedes Retinal Nerve Fiber Thinning in Nonarteritic Anterior Ischemic Optic Neuropathy. J. Neuroophthalmol. 2016, 36, 141-146. [CrossRef]

96. Kupersmith, M.J.; Garvin, M.K.; Wang, J.K.; Durbin, M.; Kardon, R. Retinal ganglion cell layer thinning within one month of presentation for non-arteritic anterior ischemic optic neuropathy. Investig. Ophthalmol. Vis. Sci. 2016, 57, 3588-3593. [CrossRef] [PubMed]

97. Kitamura, Y.; Bikbova, G.; Baba, T.; Yamamoto, S.; Oshitari, T. In vivo effects of single or combined topical neuroprotective and regenerative agents on degeneration of retinal ganglion cells in rat optic nerve crush model. Sci. Rep. 2019, 9, 101. [CrossRef] [PubMed]

98. Porciatti, V.; Schiavi, C.; Benedetti, P.; Baldi, A.; Campos, E.C. Cytidine-5'- diphosphocholine improves visual acuity, contrast sensitivity and visually-evoked potentials of amblyopic subjects. Curr. Eye Res. 1998, 17, 141-148. [CrossRef]

99. Porciatti, V. Electrophysiological assessment of retinal ganglion cell function. Exp. Eye Res. 2015, 141, 164-170. [CrossRef]

100. Froehlich, J.; Kaufman, D.I. Use of pattern electroretinography to differentiate acute optic neuritis from acute anterior ischemic optic neuropathy. Electroencephalogr Clin. Neurophysiol. 1994, 92, 480-486. [CrossRef]

101. Janáky, M.; Fülöp, Z.; Pálffy, A.; Benedek, K.; Benedek, G. Electrophysiological findings in patients with nonarteritic anterior ischemic optic neuropathy. Clin. Neurophysiol. 2006, 117, 1158-1166. [CrossRef] [PubMed]

102. Atilla, H.; Tekeli, O.; Ornek, K.; Batioglu, F.; Elhan, A.H.; Eryilmaz, T. Pattern electroretinography and visual evoked potentials in optic nerve diseases. J. Clin. Neurosci. 2006, 13, 55-59. [CrossRef] [PubMed]

103. Yau, J.W.; Rogers, S.L.; Kawasaki, R.; Lamoureux, E.L.; Kowalski, J.W.; Bek, T.; Chen, S.J.; Dekker, J.M.; Fletcher, A.; Grauslund, J.; et al. Global prevalence and major risk factors of diabetic retinopathy. Diabetes Care 2012, 35, 556-564. [CrossRef]

104. Leasher, J.L.; Bourne, R.R.A.; Flaxman, S.R.; Jonas, J.B.; Keeffe, J.; Naidoo, N.; Pesudovs, K.; Price, H.; White, R.A.; Wong, T.Y.; et al. Erratum. Global Estimates on the Number of People Blind or Visually Impaired by Diabetic Retinopathy: A Meta-analysis from 1990-2010. Diabetes Care 2016, 39, 2096. [CrossRef]

105. Roy, M.S.; Klein, R.; O'Colmain, B.J.; Klein, B.E.K.; Moss, S.E.; Kempen, J.H. The prevalence of diabetic retinopathy among adult type 1 diabetic persons in the United States. Arch. Ophthalmol. 2004, 122, 546-551. [CrossRef]

106. Raymond, N.T.; Varadhan, L.; Reynold, D.R.; Bush, K.; Sankaranarayanan, S.; Bellary, S.; Barnett, A.H.; Kumar, S.; O’Hare, J.P.; UK Asian Diabetes Study Retinopathy Study Group. Higher prevalence of retinopathy in diabetic patients of South Asian ethnicity compared with white Europeans in the community: A cross-sectional study. Diabetes Care 2009, 32, 410-415. [CrossRef] [PubMed]

107. Wong, T.Y.; Cheung, N.; Tay, W.T.; Wang, J.J.; Aung, T.; Saw, S.M.; Lim, S.C.; Tai, E.S.; Mitchell, P. Prevalence and risk factors for diabetic retinopathy: The Singapore Malay Eye Study. Ophthalmology 2008, 115, 1869-1875. [CrossRef]

108. Xie, X.W.; Xu, L.; Wang, Y.X.; Jonas, J.B. Prevalence and associated factors of diabetic retinopathy. The Beijing Eye Study 2006. Graefes Arch. Clin. Exp. Ophthalmol. 2008, 246, 1519-1526. [CrossRef] [PubMed]

109. Kempen, J.H.; O'Colmain, B.J.; Leske, M.C.; Haffner, S.M.; Klein, R.K.; Moss, S.E.; Taylor, H.R.; Hamman, R.F.; Eye Diseases Prevalence Research Group. The prevalence of diabetic retinopathy among adults in the United States. Arch. Ophthalmol. 2004, $122,552-563$.

110. Rogers, S.L.; Tikellis, G.T.; Cheung, N.; Tapp, R.; Shaw, J.; Zimmet, P.Z.; Mitchell, P.; Wang, J.J.; Wong, T.Y. Retinal arteriolar caliber predicts incident retinopathy: The Australian Diabetes, Obesity and Lifestyle (AusDiab) study. Diabetes Care 2008, 31, 761-763. [CrossRef]

111. Picconi, F.; Parravano, M.; Ylli, D.; Pasqualetti, P.; Coluzzi, S.; Giordani, I.; Malandrucco, I.; Lauro, D.; Scarinci, F.; Giorno, P.; et al. Retinal neurodegeneration in patients with type 1 diabetes mellitus: The role of glycemic variability. Acta Diabetol. 2017, 54, 489-497. [CrossRef]

112. Antonetti, D.A.; Lieth, E.; Barber, A.J.; Gardner, T.W. Molecular mechanisms of vascular permeability in diabetic retinopathy. Semin. Ophthalmol. 1999, 14, 240-248. [CrossRef] 
113. Antonetti, D.A.; Barber, A.J.; Bronson, S.K.; Freeman, W.M.; Gardner, T.W.; Jefferson, L.S.; Kester, M.; Kimball, S.R.; Krady, J.K.; LaNoue, K.F.; et al. Diabetic retinopathy: Seeing beyond glucose-induced microvascular disease. Diabetes 2006, 55, $2401-2411$. [CrossRef]

114. Fletcher, E.L.; Phipps, J.A.; Ward, M.M.; Puthussery, T.; Wilkinson-Berka, J.L. Neuronal and glial cell abnormality as predictors of progression of diabetic retinopathy. Curr. Pharm. Des. 2007, 13, 2699-2712. [CrossRef] [PubMed]

115. Das, A.; McGuire, P.G.; Rangasamy, S. Diabetic macular edema: Pathophysiology and novel therapeutic targets. Ophthalmology 2015, 122, 1375-1394. [CrossRef]

116. Van de Lagemaat, E.E.; de Groot, L.C.P.G.M.; van den Heuvel, E.G.H.M. Vitamin B12 in relation to oxidative stress: A systematic review. Nutrients 2019, 11, 482. [CrossRef]

117. Platania, C.B.M.; Giurdanella, G.; Di Paola, L.; Leggio, G.M.; Drago, F.; Salomone, S.; Bucolo, C. P2X7 receptor antagonism: Implications in diabetic retinopathy. Biochem Pharmacol. 2017, 138, 130-139. [CrossRef]

118. Solini, A.; Novak, I. Role of the P2X7 receptor in the pathogenesis of type 2 diabetes and its microvascular complications. Curr. Opin. Pharmacol. 2019, 47, 75-81. [CrossRef] [PubMed]

119. Pavlou, S.; Augustine, J.; Cunning, R.; Harkin, K.; Stitt, A.W.; Xu, H.; Chen, M. Attenuating Diabetic Vascular and Neuronal Defects by Targeting P2rx7. Int. J. Mol. Sci. 2019, 20, 2101. [CrossRef]

120. Parravano, M.; Scarinci, F.; Parisi, V.; Giorno, P.; Giannini, D.; Oddone, F.; Varano, M. Citicoline and Vitamin B(12) Eye Drops in Type 1 Diabetes: Results of a 3-year Pilot Study Evaluating Morpho-Functional Retinal Changes. Adv. Ther. 2020, 37, 1646-1663. [CrossRef] [PubMed]

121. Vujosevic, S.; Midena, E. Retinal layers changes in human preclinical and early clinical diabetic retinopathy support early retinal neuronal and Muller cells alterations. J. Diabetes Res. 2013, 2013, 905058. [CrossRef]

122. Scarinci, F.; Picconi, F.; Virgili, G.; Giorno, P.; Di Renzo, A.; Varano, M.; Frontoni, S.; Parravano, M. Single Retinal Layer Evaluation in Patients with Type 1 Diabetes with No or Early Signs of Diabetic Retinopathy: The First Hint of Neurovascular Crosstalk Damage between Neurons and Capillaries? Ophthalmologica 2017, 237, 223-231. [CrossRef] [PubMed]

123. Sun, Z.; Tang, F.; Wong, R.; Lok, J.; Szeto, S.K.H.; Chan, J.C.K.; Chan, C.K.M.; Tham, C.C.; Ng, D.S.; Cheung, C.Y. OCT Angiography Metrics Predict Progression of Diabetic Retinopathy and Development of Diabetic Macular Edema: A Prospective Study. Ophthalmology 2019, 126, 1675-1684. [CrossRef] [PubMed]

124. Scarinci, F.; Picconi, F.; Virgili, G.; Varano, M.; Giorno, P.; Frontoni, S.; Parravano, M. Microvascular impairment as a biomarker of diabetic retinopathy progression in the long-term follow up in type 1 diabetes. Sci. Rep. 2020, 10, 18266. [CrossRef]

125. Quattrini, C.; Tavakoli, M.; Jeziorska, M.; Kallinikos, P.; Tesfaye, S.; Finnigan, J.; Marshall, A.; Boulton, A.J.; Efron, N.; Malik, R.A. Surrogate markers of small fiber damage in human diabetic neuropathy. Diabetes 2007, 56, 2148-2154. [CrossRef] [PubMed]

126. Fogagnolo, P.; Melardi, E.; Tranchina, L.; Rossetti, L. Topical citicoline and vitamin B12 versus placebo in the treatment of diabetes-related corneal nerve damage: A randomized double-blind controlled trial. BMC Ophthalmol. 2020, 20, 315. [CrossRef] [PubMed] 